\title{
An analysis of transitivity in Cheyenne*
}

\author{
Avelino Corral Esteban \\ Universidad Autónoma de Madrid \\ avelino.corral@uam.es
}

\begin{abstract}
Verbal typology in Cheyenne has traditionally been analyzed following the terminology that Bloomfield used in 1946 in order to describe Proto-Algonquian verbal classes. That terminology mixed two syntactic concepts, namely valence and transitivity, in order to refer to the different types of verb in Algonquian languages. Although in Cheyenne the verbal paradigms are available in a number of excellent sources (Petter 1952; Meeussen 1962; Leman 1980b; Russell 1987), this article attempts to provide a more comprehensive description of the verbal system in Cheyenne by classifying Cheyenne predicates into three groups in terms of their semantic valence, that is the number of core arguments they require: (1) one-place predicates, which are accompanied by only one core argument, (2) two-place predicates, which have two core arguments, and (3) three-place predicates, which include up to three core arguments. This classification will prove more accurate than the traditional four-way division, since it captures better the existence of four further distinct verbal paradigms, namely those illustrated by the construction including an inanimate subject and an animate patient, the Unspecified Agent construction, and the ditransitive constructions with inanimate theme, and the ditransitive construction with theme.

On the other hand, the study of three-place predicates will occupy a special place in the last part of the article, since it raises interesting questions, such as the number of arguments coded in the verb, the semantic role played by these arguments, and the possible existence of alternations and splits. Furthermore, the analysis of ditransitive constructions will allow us to classify this type of predicate in Cheyenne in terms of the concept of alignment, which refers to the comparison of the properties of the core arguments of the predicate.
\end{abstract}

Keywords: Cheyenne; transitivity; semantic valence; three-place predicates; ditransitive alignment

\section{Introduction}

Traditionally verbs have usually been divided into three categories in terms of their transitivity: intransitive verbs, (mono)transitive verbs, and ditransitive verbs, according to the number of objects that they require syntactically. Unlike the transitivity of a verb, which only considers the objects, there is a related concept called verb valence or valency (Tesnière 1959),

\footnotetext{
* Financial support for this research has been provided by the Spanish Ministry of Economy and Competitiveness (MINECO), FFI2011-29798-C02-01/FILO.
} 
in which all the arguments taken by the verb are considered, including the subject.

Furthermore, it is also useful to distinguish between two different types of valence, namely syntactic valence and semantic valence, and these do not necessarily coincide. For instance, in a passive sentence, the syntactic valence of the verb is reduced from two to one since the by-phrases are peripheral adjuncts rather than obligatory core arguments of the passive verb. Yet, they continue to be semantic arguments of the verb because the predicate requires an agent NP, which is represented by that adjunct. In this paper, although I will also make use of the traditional nomenclature used to describe verbs in the Algonquian languages (Bloomfield 1946), which mixes both concepts, in order to refer to the different types of verb in Cheyenne, I will divide Cheyenne predicates into three groups in terms of their semantic valence, which makes reference to the number of core arguments required by the predicate, which can be represented either by dependent NPs or by pronominal markers within the verb.

Once transitivity has been introduced, the remainder of the paper is organized as follows. In section 2, I will classify Cheyenne within the Algonquian group of languages and provide a brief description of its basic morpho-syntactic features. In section 3, I will give a detailed account of the hierarchical alignment exhibited by this language. In section 4, I will outline the basics of the relevant Cheyenne morphology and syntax in simple one-participant and two-participant constructions by developing and studying the different verbal paradigms of the Cheyenne verbal system, ${ }^{1}$ which are determined by the concepts of transitivity and animacy. Then, in sections 4 and 5, I will undertake a deep analysis of three-place predicates, which will allow us to classify Cheyenne as a language with a bias towards secundative alignment, in accordance with terminology put forward by Siewierska (2003) and Haspelmath (2005). Finally, section 6 closes the paper with the main conclusions to be drawn, as well as some implications for further research.

${ }^{1}$ In Cheyenne, as in the other Algonquian languages, there are three major divisions of verb forms, commonly named 'orders' following Bloomfield (1946, 97-103): Independent, Conjunct, and Imperative. In this article, I will limit myself to illustrating the verb patterns found in the Independent Order (in broad terms, the order occurring in main clauses). 


\section{Basic morpho-syntactic characteristics of Cheyenne}

Considering the morphological complexity of the Cheyenne ${ }^{2}$ language, it seems appropriate to include a brief section describing its basic morphosyntactic characteristics, such as word order, argument type, marking, branching, and alignment. Cheyenne is an Algonquian language classified within the Plains Algonquian group, whose languages (Cheyenne, Blackfoot, Arapaho, Gros Ventre) show a significant divergence with respect to Proto-Algonquian both phonologically and lexically.

According to conventional morphological typology, Cheyenne is considered a polysynthetic language, since it exhibits a high morpheme-toword ratio, fairly regular morphology and verb forms that tend to include morphemes that stand for the different arguments in the clause: ${ }^{3}$

(1) Ná-ohkè-sáa-'oné'seóme-pèhéve-tsėhésè-sto'ané-he.

(1)-regularly-NEG-truly-well-Cheyenne-pronounce.AI-NEG

'I truly don't pronounce Cheyenne very well.'

(Fisher et al. 2006, 179)

2 The Cheyenne language, known as Tsêhésenêstsestôtse in the native tongue, is spoken on the Northern Cheyenne Indian Reservation in southeastern Montana and on the Cheyenne-Arapaho Indian Reservation in central Oklahoma by approximately 2,000 individuals. The data in this paper come mainly from my native consultants, supplemented with existing language materials such as a Cheyenne Grammar (Leman 1980b) and two collections of texts (Leman 1980a; 1987) and a Cheyenne Dictionary (Fisher et al. 2006). I wish to express my gratitude to my anonymous language consultants, native speakers of Cheyenne with whom I have conducted fieldwork since 2010, for kindly sharing their knowledge of this language with me, and Wayne Leman and Robert Van Valin for their continued support and their valuable and insightful comments, which have helped to improve the quality of the manuscript considerably. I glossed and translated all of the examples that occur in the paper, even the ones from the supplementary sources. Needless to say, all errors remain my sole responsibility.

${ }^{3}$ Abbreviations used in this paper: (1) - first person, (2) - second person, (3) - third person/proximate singular agreement; $(4)$ - fourth person/obviative agreement; (11) - first person plural exclusive: (12) first person plural inclusive; (22) - second person, (33) - third person plural agreement; SG - singular, PL - plural; AN - animate, INAN - inanimate; II - intransitive inanimate verb, AI - animate intransitive verb, TI - transitive inanimate verb, TA - transitive animate verb, DITR - ditransitive verb; DIR - directional; ASP - aspect; FUT - future, PAST - past; IF - Illocutionary Force; Q - interrogative IF, IMP - imperative IF; DEIC - deictic; LOC - locative case marking; OBV - obviative case marking; BEN - benefactive case marking; NP - Noun Phrase; REFL - reflexive; REC - reciprocal; sing - singular, pl - plural; DO - direct object, $\mathrm{IO}$ - indirect object; $\mathrm{A}$ - agent, $\mathrm{T}$ - theme, $\mathrm{R}$ - recipient, B - beneficiary. 
Cheyenne is a discourse-configurational language (Hale 1983; Jelinek 1984; É. Kiss 1995), since it attaches more importance to the encoding of the discourse functions topic and focus than that of the syntactic functions such as subject and object. In this language, the clause constituents are ordered according to the discourse functions and, therefore, the syntactic functions cannot be deduced from their position in the clause. Thus, the word order is so flexible that it allows all kinds of possible combinations as to the position of the major constituents, that is, subject, verb and object (SOV, VSO, VOS, OSV or OVS) for pragmatic reasons:

(2) SVO

Ného’ééhe é-véstähém-ó-ho hetanóho.

my.father (4)-help.TA-4:5-SG.A+5.P man (OBV)

'My father helped the man.' (Redfox \& Leman in Leman 1980a, 19)

(3) SOV

Tse'tohe kảse'ééhe sétöhkeho é-x-hestan-óhoon-e.

DEIC young.woman rope (3)-PAST-take-with.hand.TI-3:I

'This young lady took the rope.'

(4) VOS

Mó-me'-évè-hé-heškéhévóht-a ne-ma'kaatóhkonéhanótse tsé'tóhe.

would-surely-about-ASP-dirty.TI-3:I our-buckets DEIC

'This one would surely dirty our buckets.'

(Howlingcrane \& Leman in Leman 1980a, 38)

(5) VSO

É-sta-něšěševátamósest-o(-ho) hátšeške háhkotaho.

(3)-PAST-have.pity.on.TA-3:4-SG.A+4.P ant grasshopper (OBV)

'The ant had pity on the grasshopper.' (Flyingout \& Leman in Leman 1980a, 28)

(6) OVS

Moméheome é-h-nèh-na'h-ae-vó nótảxé-vé'hó'e.

whole.families (3)-PAST-? ${ }^{4}$-kill.TA-4:33-4.A+33.P warrior.whiteman (OBV)

'The soldiers killed whole families.' (Strangeowl \& Leman in Leman 1987, 37)

(7) OSV

Kảhamaxè néhe he'e é-ta-möheana-nò-(o)tse.

sticks DEIC woman (3)-over.there-gather.TI-3:II+II.P-II.P

'That woman gathered up the sticks.'

(Leman 1991, 3)

${ }^{4}$ This preverb could be an intensifier. 
The Cheyenne language appears to be a clear example of a pronominalargument language, since it expresses all the arguments of the verb pronominally with overt lexical Reference Phrases (RPs) being optional. Likewise, Cheyenne is a head-marking language because all grammatical relations are coded in the verb, which is the head of the clause, rather than in the NPs, although the latter may also mark obviative case and sporadically instrumental case:

(8) Ná-na'h-o-óo šéšènovoto.

(1)-kill.TA-1:33-33.P snakes

'I killed the snakes.'

(9) Ná-na'h-o-o'o.

(1)-kill.TA-1:33-33.P

'I killed them.'

Regarding the verb/satellite-framing parameter, Cheyenne is not such a clear-cut case. On the one hand, it appears to be a satellite-framed language since it uses a verb plus a particle to express motion, as in $e^{\prime} e o h t s e^{5}$ 'go up' or e'ehné 'walk up'. On the other hand, however, it does not describe the path of motion with a verb plus a separate particle, but by means of a preverbal particle plus a verbal stem fused within a word. Thus, we could argue that Cheyenne shows features of both satellite-framed and verb-framed languages and its classification in one of these categories will depend on how we regard the verbal complex: if we consider the verb complex as only a word (i.e., 'sentence syntax': relationship between the words inside a sentence), it would be classified as a verb-framed language since the concept of motion is encoded in the verb as part of its root meaning; however, if we consider the verb complex as a whole sentence (i.e., 'word-syntax': relationship between the morphemes inside a word), then the morphemes would function as words, and each of them would be distinct from each other with a separate meaning, thereby fulfilling the condition that satellite-framed languages have the concept of motion encoded in a separate particle (i.e., 'satellite') associated with a verb.

As regards branching, it is very difficult to decide if Cheyenne can be considered an example of a left- or right-branching language owing to the fact that it does not favour a specific canonical word order and the objects in this language can therefore appear before or after the verb.

\footnotetext{
${ }^{5}$ e'eohtsé $\rightarrow e^{\prime}(e)$ 'up' + ohtsé 'go'

${ }^{6} e^{e}$ ehné $\rightarrow e^{\prime}(e)$ 'up' + ehné 'walk'
} 
Nevertheless, it shares a characteristic with left-branching languages since adjectives in this language normally appear in the form of prenominal particles (e.g., ma háhkèhe 'old' + vého'e 'whiteman' $\rightarrow$ ma háhkèhevého'e 'old whiteman'). Regarding the use of adpositions, although these elements normally appear as preverbal particles embedded into the verb complex, their meanings can sometimes be expressed by nominal suffixes, ${ }^{7}$ which would function as postpositions, which also reflects a characteristic typical of left-branching languages.

\section{Hierarchical alignment in Cheyenne}

In addition to all these properties, the Cheyenne language, like the other Algonquian languages, constitutes a clear example of a direct-inverse language with hierarchical alignment. A direct-inverse language is one where clauses with transitive verbs can be expressed by using either a direct or an inverse construction and, consequently, the morpho-syntactic markers vary with respect to the position of each argument in terms of a hierarchy, hence direct-inverse languages are generally said to have hierarchical alignment. Thus, in Cheyenne the participants are arranged on an Animacy-Topicality scale, which is characteristic of all Algonquian languages (figure 1). ${ }^{8}$

The hierarchy "2nd $>1$ st $>3$ rd $>4$ th $>$ I" adheres to the universal ranking of the local participants (i.e., first and second person) over third persons, since the former are considered to have more animacy and salience or topicality than the latter. Besides respecting this universal ranking, the Animacy-Topicality hierarchy presents two further distinctions: one, the second person is ranked in this language over the first person; and two,

${ }^{7}$ For example:

(i) Ná-vé’̌̌e-oom-a-a'e kảhámáxe.

(1)-with-hit.DITR-3:1:I-I.T stick

'He hit me with a knife' （preverbal particle; Fisher et al. 2006, 315)

(ii) Ná-oom-a kảhamáxéhéva.

(1)-hit.TA-3:1 stick-INST

'He hit me with a knife.' (nominal suffix; Leman 1980b, 171)

Although both options seem to be correct, the second option appears to be a more modern form, which could have appeared at a later stage in its development towards a more analytical language.

8 There appear to be a few Algonquian languages like Blackfoot (Bliss \& Jesney 2005) that rank first person over second person. 


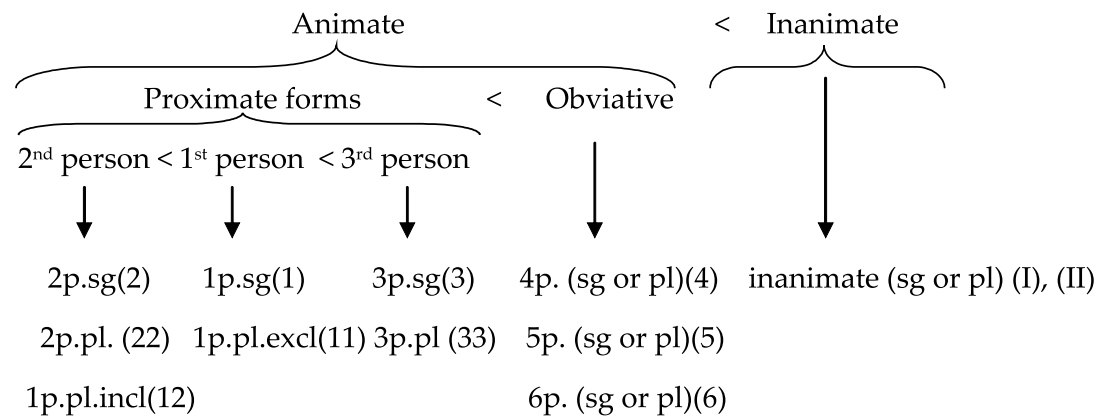

Figure 1: Animacy-Topicality hierarchy of Cheyenne

the division of the less topical participants, that is, the third person participants into two different types, namely the proximate and the obviative, on the basis of discourse topicality.

In Cheyenne, personal pronouns are not realized by free words; ${ }^{9}$ rather, they appear as particles attached to the verbal complex both in a main clause and in a subordinate clause. These particles are divided into two groups - prefixes and suffixes - that are very closely related because they carry complementary grammatical information in terms of person, number, animacy, salience and syntactic function. The marking of grammatical relations is conveyed by the prefixes and the suffixes simultaneously and we cannot therefore separate the information provided by each of the affixes and assign each grammatical function a different affix. Consequently, it would not be appropriate to take either the prefixes or the suffixes exclusively into consideration when it comes to finding words or particles that perform the same function as personal pronouns in English, that is, expressions providing information about the person of the participants involved in the situation denoted by the predicate. Thus, the prefix and the suffix do not correspond to the syntactic functions of subject and object respectively. Instead, in this language the grammatical relations of subject and object are fused with the agreement markers, so that both the prefix and the suffix must be analysed as a whole.

\footnotetext{
${ }^{9}$ As shown in Leman $(1985,19 ; 25)$, this language presents a number of expressions whose function is analogous to that of personal pronouns, although their meaning has an emphatic sense making them optional elements. Furthermore, it is not clear whether these expressions should be considered as free forms, since they are fully inflected verbal forms in both Independent and Conjunct Orders.
} 
In the Independent Order ${ }^{10}$ the verbal prefix, which appears to be attached at the initial position of the verbal complex, is the element that signals the most pragmatically salient participant according to the hierarchy. In Cheyenne the personal prefixes present only one paradigm and, consequently, they remain invariable regardless of the semantic role (thematic role) played by the participants in the clause (table 1).

Table 1: Personal pronouns realized by personal prefixes in Cheyenne (Leman 1980b)

\begin{tabular}{ll}
\hline Person & Affix \\
\hline 1st person singular (1) & ná-... \\
2nd person singular (2) & né-... \\
3rd person singular (3) & é-... \\
1st person plural exclusive (11) & ná-.. \\
1st person plural inclusive (12) & né-... \\
2nd person plural (22) & né-... \\
3rd person plural (33) & é-.. \\
4th/5th/6th person (4) & é-... \\
Inanimate (I) & é-... \\
\hline
\end{tabular}

Thus, in Cheyenne the coding of the prefix depends on the nature (i.e., person and animacy) of the participants involved, rather than on the type of the predicate (i.e., stative vs. active) ${ }^{12}$

${ }^{10}$ Apart from the different information they convey (i.e., the Independent Order includes all verb forms other than imperatives which can stand alone and the Conjunct Order is used for all dependent verb forms), the Conjunct also differs from the Independent Order in its relative poverty of agreement morphology, reflected in the simplification of its suffixal agreements, and the different function of its prefix. Thus, whereas in the Independent Order, the prefix serves to express grammatical information in terms of the most pragmatically salient person, in the Conjunct Order it indicates the verb mood (indicative, subjunctive, participle, etc.).

${ }^{11}$ Cheyenne has two different first person plural forms: the inclusive option is used to refer to 'both you and I (and maybe others)' (represented by '12'), that is, it includes the person(s) addressed; by contrast, the exclusive form is used when we only want to refer to 'we' (represented by '11'), thereby excluding the person(s) addressed.

${ }^{12}$ In Algonquian languages the animate/inanimate distinction is grammatical rather than purely semantic. Therefore, although there is a close semantic correlation between the concept of animacy and the notion of 'having life', this identification is not completely predictable. Thus, whereas names referring to human beings, 
(10) Né-ho'sotahe.

(2)-be.dirty.AI

'You are dirty.'

(11) Né-táhoo'e.

(2)-ride.AI

'You ride / you are riding.'

(12) a. Né-óom-e.

(2)-hit.TA-2:1

'You hit me.'

b. Né-oom-ätse.

(2)-hit.TA-1:2

'I hit you.'

As we can see from examples (10), (11), and (12a-b), the form of the personal prefixes remains invariable regardless of the type of verb and the semantic role played by the participants in the clause. The second person is considered the highest ranking person in terms of the hierarchy in Cheyenne and this means that it is regarded as the most prominent person in a situation. This will be reflected in the verb in the following way: whenever a second person participant is involved in a clause, regardless of whether it has the grammatical function of subject or object, the verb will begin with the second person prefix né-.

The second most prominent participant is represented by the first person, followed by the third person and finally by the obviated participants. The lowest person in terms of hierarchy is the inanimate thing. Consequently, depending on whether an action respects the hierarchical order or not, we will say that the construction is direct or inverse (figure 2).

The direct construction is used when the subject of the transitive clause outranks the object in salience or animacy and the inverse construction is used when the object outranks the subject:

(13) Direct construction

Né-méhox-e.

(2)-love.TA-2:1

'You love me.'

animals and plants (living entities) are always animate and most names referring to objects (non-living entities) are normally considered inanimate, there are also some names referring to objects (e.g., hóhtséme 'ball', hoohēō'o 'flag', and nèhahtsenáhestotse 'napkin') that are classified as animate. 


$\operatorname{direct}\left|\begin{array}{l}2 \text { second person } \\ 1 \text { first person } \\ 3 \text { third person } \\ 4 \text { fourth person } \\ \text { I/II inanimate person }\end{array}\right|$ inverse

Figure 2: Direct and Inverse constructions in Cheyenne (Leman 1980b, 22)

(14) Inverse construction

Né-méhot-ätse.

(2)-love.TA-1:2

'I love you.'

In (13) and (14) both verbal forms present the same prefix né-, which indicates a second person participant, but the grammatical function of this argument is not known until the suffix is analysed. Thus, in (13) the suffix - $e$ indicates that the construction is direct and that this is a monotransitive construction with two participants, namely, a second person participant functioning as subject and a first person participant performing the role of object. In (14) the suffix - atse also indicates that this is a monotransitive construction involving two participants, but now it shows inverse alignment, since the subject, a first person participant, is lower in terms of hierarchy than the object, a second person participant. As a summary, in a direct construction the prefix indicates the person of the subject and, in an inverse construction, the prefix signals the person of the object.

As mentioned above, Cheyenne not only uses prefixes to determine the person of the participants, but also has a myriad of final particles or suffixes covering a wide range of grammatical information (i.e., person, number, animacy, salience and syntactic function) concerning the obligatory arguments of the predicate:

(15) Ná-hoo' e nả-htona he-màheó-ne.

(1)-stay.AI my-daughter her-house-LOC

'I am staying at my daughter's house.' 
(16) É-nè-héóhtse-oó Méave'ho'e-no.

(3)-DIR-come.from.AI-33 Lame Deer-LOC

'They came from Lame Deer.'

In the examples given above we can observe that, on the one hand, the prefixes $n a ́$ - in (15) and é- in (16) indicate the person of the only core argument of their respective predicates. On the other hand, the suffixes $-\varnothing$ in (15) and $-o^{\prime} o$ in (16) provide the appropriate grammatical information in terms of the person, number, animacy and syntactic function of the only core argument, hence the grammatical information provided by both prefixes and suffixes is complementary.

Finally, it is important to note the presence of an extra person named 'fourth person' or 'obviative'. This fourth person, represented by both a verbal suffix and a nominal suffix (typically -o/-ho/-óho) appears in two different situations. Firstly, the obviated element can represent the less salient third person participant in a situation where there are two third person participants:

(17) Ná-néso é-tónoom-ó-ho he-vésenóho. my-child (3)-wait.for.TA-3:4-SG.A+4.P his-friend (OBV)

'My child waits/is waiting for his friend.'

Secondly, obviation is also produced when there is a third person participant possessed by another third person participant:

(18) Peter he-měšemo é-sénoéstomo'h-ó-ho.

Peter his-grandfather (OBV) (4)-be.kind.AI-4-4

'Peter's grandfather is kind.'

Although, normally, there are only two third person participants in a sentence, there could be more than two in specific situations potentially involving the presence of a fifth or even a sixth person in the same sentence: ${ }^{13}$

13 Gensler $(2003,200)$ argues that "two object NPs may almost never co-occur", and this statement appears to be true for Cheyenne since my native consultants point out that, although this sentence is grammatically correct, sentences including more than one NP are not very common in natural discourse. Furthermore, according to the same author (ibid., 194), "the double-object construction turns out not to be particularly common in the world - even in heavily polysynthetic North America there are surprisingly few cases". 
(19) Tsé’to $={ }^{14}$ hé'e náhkỏhóho DEIC=woman bear (OBV)

'é-vóo'sèh-ó-no-to he-mé'ěškevotamo.

(3)-show.DITR-3:4:5-5.T-3/4.A/R+5.T her-baby (OBV)

'This woman showed her baby the bear.'

The obviation marker does not distinguish between singular and plural number and therefore an obviated participant, whether it is a fourth, fifth or sixth person, and regardless of its number, will always have the same form.

\section{The Cheyenne verbal system}

An important difference between the prefixes and suffixes in Cheyenne is that, apart from the fact that the suffixes contain more grammatical information, the prefixes are invariable with respect to transitivity, that is, their form is the same regardless of whether the verb is transitive or intransitive or whether the participant they refer to is animate or inanimate, as distinct from suffixes, since both the transitivity of the verb and the animacy of the participants have an influence on their form.

Transitivity and animacy are the two most crucial criteria used to classify verbs in Algonquian languages. In Cheyenne, the verbs are traditionally divided into four types, as with the rest of the Algonquian languages (Bloomfield 1946), according to these two criteria. This four-way division leads to the following verb types: inanimate subject + intransitive verb (II), animate subject + intransitive verb (AI), animate subject + transitive verb + inanimate object (TI), and animate subject + transitive verb + animate object (TA). Although in Cheyenne the verbal paradigms are available in a number of excellent sources (Petter 1952; Meeussen 1962; Leman 1980b; Russell 1987), I find it useful to review some of the basic features of the four different types of verbal classes with the aim of providing a suitable background to a comprehensive analysis of its ditransitive verbs, which differ in relation to the animacy and the number of the participant functioning as direct object.

\footnotetext{
${ }^{14}$ This symbol indicates that the demonstrative has been shortened: tsétohe hé $e \rightarrow$ tséto=hée.
} 


\subsection{One-place predicates}

The marking in one-argument predicates (i.e., intransitive verbs) in Cheyenne differs only in terms of the animacy of its only participant, which functions as subject. Although there are more AI than II stems, which is only to be expected given that inanimate subjects are not nearly as common in the real world as animate ones, the latter are particularly numerous in Cheyenne. As regards their structure, the form of the prefix for the inanimate subject coincides with that of the third person and obviated participant, namely the prefix é-, the II stems end in -a (e.g., aséväho 'tá 'start (of a car)', néšèho'tá 'be hot', etc.), -e (e.g., péhéva'é 'be good', a'enóneotse 'become dark', etc.), or -o (e.g., émoosó 'be silent', estsévóéo 'sink', etc.), and only present plural suffixes (table 2 ).

Table 2: Prefixes and suffixes of an inanimate intransitive (II) stem in Cheyenne

\begin{tabular}{ll}
\hline II - Intransitive verb & Inanimate subject \\
\hline Inanimate singular & é-... \\
Inanimate plural & é-... -nèstse \\
\hline
\end{tabular}

(20) Hátó=ho'honáevose é-háahpē'o.

DEIC $=$ mountain (I)-be.very.big.II

'That mountain is huge.'

(21) Maahótse é-ma'éveotsé-nėstse.

arrows (I)-be.blooded.II-II

'The arrows are stained with blood?'

(Fisher et al. 2006, 124)

The AI class includes a lot of verbs whose subject is animate and that require no object. Cheyenne $\mathrm{AI}$ stems normally end in - $e^{15}$ (e.g., kähaneotse 'be tired', o hohné 'play baseball', etc.) but there are also some AI stems ending in -a (e.g., méhová 'be hairy') or -o (e.g., ma hāo'o 'be large'). Unlike in the plural, the singular forms have no inflectional endings and only differ with respect to the prefix (table 3 ).

${ }^{15}$ Leman (1980b, 23), in his account of the basic structure of Cheyenne verbs, regards the ending - $e$ in AI verbs as an "abstract final" particle and therefore does not consider this ending to be part of the verbal root. Thus, in a verb like ho'soo'e 'dance', the root would just be ho'soo and the stem (root + final) would be ho'soo'e. 
Table 3: Prefixes and suffixes of an animate intransitive (AI) stem in Cheyenne

\begin{tabular}{ll}
\hline AI - Intransitive verb & Animate subject \\
\hline 1st person singular & ná-... \\
2nd person singular & né-... \\
3rd person singular & é-... \\
1st person plural exclusive & ná-...e-eme \\
1st person plural inclusive & né-...-ema \\
2nd person plural & né-...-ēme \\
3rd person plural & é-...-óo \\
4th/5th/6th person & é-...-óho \\
\hline
\end{tabular}

(22) É-pèhéve-tano-óo.

(3)-good-feel.AI-33

'They are happy'

\subsection{Two-place predicates}

In relation to (mono-)transitive verbs, which have two obligatory arguments with the syntactic functions of subject and object, there is an interesting fact regarding the pronominal markers. As stated above, in Cheyenne there is no one-to-one correspondence between the pronominal markers and the obligatory arguments, since it is not possible to distinguish the morphemes that stand for the subject or object respectively and, instead, both the agreement markers must be analysed as a whole.

The TA class, where both the subject and object participants are always animate, makes up the biggest group of verbs in Cheyenne and its paradigm of affixes illustrates its rich morphological system, which avoids any case of ambiguity. Owing to the size of the chart showing this paradigm, it will be given in Appendix (table 12).

(23) Ná-e'hahtov-oo'o tsé-héstoo'éšeehaese. ${ }^{16}$

(1)-respect.TA-33.P my.parents

'I respect my parents.'

16 The expression tséhéstoo'ešehaese is indeed a participial verbal form in the Conjunct Order formed by the complementizer tsé-, the TA stem héstoo'éšeeh meaning 
(24) Né-pèhév-atam-àtse.

(1)-good-regard.TA-1:2

'I like you.' (lit. 'I regard you as good.')

There are also a large number of verbs that require an animate subject and an inanimate object. They are called TI stems and the extent to which there is distinctive singular and plural object marking in these verbs shows considerable variation across the Algonquian languages. Thus, unlike other Algonquian languages such as, for example, Cree (Wolvengrey 2011), in Cheyenne the suffixes modify their form depending on the number of the object (table 4).

Table 4: Prefixes and suffixes of a transitive inanimate (TI) stem in Cheyenne

\begin{tabular}{|c|c|c|}
\hline $\begin{array}{l}\text { TI - Transitive verb } \\
\text { Animate subject }\end{array}$ & $\begin{array}{l}\text { Inanimate object } \\
\text { Singular }\end{array}$ & $\begin{array}{l}\text { Inanimate object } \\
\text { Plural }\end{array}$ \\
\hline 1st person singular & ná-... - a/e & ná-... - anòtse/enótse \\
\hline 2nd person singular & né-... - a/e & né-... - anòtse/enótse \\
\hline 3rd person singular & é-... - a/e & é-... - anòtse/enòtse \\
\hline 1st person plural excl. & ná-... - ánóne/énóne & ná-... - anonėstse/enonėstse \\
\hline 1st person plural incl. & né-... - anone/enone & né-... - anonèstse/enonèstse \\
\hline 2nd person plural & né-... - ánóvo/énóvo & né-... - anovòtse/enovỏtse \\
\hline 3rd person plural & é-.. . - ánóvo/énóvo & é-... - anovòtse/enovòtse \\
\hline 4th person & é-. . . - otse/etse & é-... - otsenótse/etsenótse \\
\hline
\end{tabular}

(25) É-nèhpo'a’o’'ts-e hénétoo'o.

(3)-lock.TI-3:I door

'He locked the door.'

(26) Né-évo’èhāhtse-nò-(o)tse évo'sóeseonòtse.

(2)-break.TI-2:II+II.P-II.P toys

'You broke the toys.'

There is, furthermore, another verbal class, commonly referred to as the 'TA inanimate agent' paradigm with only a few verbs and involving an inanimate agent acting upon an animate patient, that is, the subject is inanimate and the object, animate. It is particularly noteworthy that Che-

'raise', and the agreement marker -aese indicating an obviative agent and a third person singular patient, hence its literal meaning would be 'those who raised me'. 
yenne shows a different paradigmatic set with respect to other Algonquian languages, since in this language this construction is also built on a TA paradigm although its inflections are identical to the TI forms, rather than to the AI or TA forms as might be expected (table 5).

Table 5: Prefixes and suffixes of a transitive verb with inanimate subject and animate object in Cheyenne

\begin{tabular}{|c|c|c|c|c|}
\hline $\begin{array}{l}\text { Transitive verb } \\
\text { Inanimate subject }\end{array}$ & $\begin{array}{l}\text { 1st p. sing. } \\
\text { (1) }\end{array}$ & $\begin{array}{l}\text { 2nd p. sing. } \\
(2)\end{array}$ & $\begin{array}{l}\text { 3rd p. sing. } \\
(3)\end{array}$ & $\begin{array}{l}\text { 1st p. pl. excl. } \\
(11)\end{array}$ \\
\hline Inanimate & ná-...-oo’e & né-...-oo'e & é-...-oóe & ná-. . . -óénóne \\
\hline Singular & ná-...-aa'e & né-...-aa'e & é-...-aa'e & ná-... -aenone \\
\hline Inanimate & ná-... -óenòtse & né-.. . -óenòtse & é-. . .óenòtse & ná-... -óenonėstse \\
\hline Plural & ná-... -aenòtse & né-... -aenotse & é-... -aenòtse & ná-... -aenonèstse \\
\hline $\begin{array}{l}\text { Transitive verb } \\
\text { Inanimate subject }\end{array}$ & $\begin{array}{l}\text { 1st p. pl. incl. } \\
(12)\end{array}$ & $\begin{array}{l}\text { 2nd p. pl. } \\
(22)\end{array}$ & $\begin{array}{l}\text { 3rd p. pl. } \\
(33)\end{array}$ & $\begin{array}{l}\text { 4th p. } \\
(4)\end{array}$ \\
\hline Inanimate & né-. . . -óenone & né-. . . -óénóvo & é-.. . -óénóvo & é-... -óetse \\
\hline Singular & né-... -aenone & né-. . . -aenóvo & é-... -aenóvo & é-. . . -aetse \\
\hline Inanimate & né-. . . -óenonėstse & né-... -óenovòtse & é-. . . -óenovòtse & é-. . .óetsenòtse \\
\hline Plural & né-. . .-aenonėstse & né-... -aenovòtse & é-. . . -aenovòtse & é-. . . -aetsenòtse \\
\hline
\end{tabular}

All the forms present in table 5 show two options. There is, however, no principle ruling the use of one or another option since the choice appears to be lexically based:

(27) Kàhámáxe ná-a'ta'-oo'e.

stick (1)-hit.TA.I:1-I.A+1.P

'The stick hit me.'

(28) Ována'xanéstahtòtse né-ho'èhót-ae-no-ne.

peace (2)-come.to.TA-I:12-I.A+PL.P-12.P

'Peace came to us.'

(29) Ho’évohkòtse ná-háomóhtảhé'(ov)-oo’e.

meat (1)-cause.to.be.sick.TA.I:1-I.A+1.P

'The meat made me sick.'

(Fisher et al. 2006, 47)

In the preceding discussion, a considerable number of examples have exemplified the four-way classification of the Cheyenne verbal system. However, one construction that has not yet been detailed is the "Unspecified Actor" construction (Hockett 1996), which is very similar to the English passive. According to Petter $(1952,39)$ and Leman $(1989,55 ; 87)$, this "passive- 
like" construction consists in adding the suffix -ane to the verbal stem of a transitive predicate, with the exception of the third person, which takes $-e .^{17}$ This construction is illustrated in the following examples including both TA stems (30)-(31) and TI stems (32)-(33):

(30) Ná-hestáots-ane Mo'òhtávỏheomené-no.

(1)-give.birth.to.TA-X:1 Lame.Deer-LOC

'I was born in Lame Deer.'

(31) Peter é-heševéh-e.

Peter (3)-call.TA-X:3

'He is called Peter./His name is Peter.'

(32) Ameohestòtse é-hóxe'án-e.

car (I)-clean.TI-X:I

'The car was cleaned.'

(33) Amóa’óvảhtsestòtse é-pèhéván-e.

bike (I)-fix.TI-X:I

'The bike was fixed.'

This construction could be compared to an English-style passive in the sense that the syntactic valence of the verb seems to be reduced by one whereas its logical structure remains intact. Wolvengrey $(2011,158)$ argues for Cree that these are not "actorless" constructions, since they do "[...] not remove the semantic argument from the understanding of the state of affairs". According to him, the evidence that this agent is present, despite not being indexed and specified on the verb, comes from the fact that this construction does not permit the lexicalization of the agent. In Cheyenne it is not possible to include a lexicalized agent with this construction either:

(34) *Vo’èstane ameohestòtse é-hóxéan-e.

someone car (I)-clean.TI-X:I

'Someone cleaned the car.'

(35) Vo’èstane ameohestòtse é-hóxe’an-a.

someone car (3)-clean.TI-3:I

'Someone cleaned the car.'

17 With a plural object both -ane- and - $e$ are followed by inflectional suffixes (i.e., -néme (11), -nema (12), néme (22), -o’o (33) 
As we can see in (35), the presence of a lexical element, namely the indefinite pronoun vo'éstane 'someone', forces the agent to be interpreted as a third person participant, reflected in the form of the pronominal affix $-a$.

Taking into account that we are dealing with a little-documented language compounded by the fact that these examples do not abound in literature, it is seemingly difficult for us to gauge if these two suffixes should be analysed as markers cross-referencing an agent impersonalizer or, in contrast, as passive voice markers. However, given the close similarity that exists between these two constructions, it appears plausible that this verbal paradigm originally reflected an agent so indeterminate, general or easily inferred from the context that it stopped being co-referenced by the verb. Subsequently, this construction gradually underwent grammaticalization becoming a construction similar to the English passive with the only difference being that the former does not permit the lexicalization of the agent. This may be evidence enough for us to claim that this construction is, in fact, different from the English passive.

This language also makes use of valence-increasing devices, ${ }^{18}$ whose influence is reflected in the morphology of the verbal stem. For instance, if the verb increases its valence, that is, if an intransitive verb becomes transitive by adding another core argument, its stem will show a modification. There is a correlation between transitivity and the abstractness of the meaning of the predicate, so that the intransitive use, e.g., vóosané 'see', denotes a more abstract or general meaning and the transitive use, e.g., vóóhtá 'see something' or vóom 'see someone', a more specific meaning. In Cheyenne the specific meaning is usually accompanied by the presence of a medial particle - $t$ - for inanimate objects and $-(e) m$ - or -tov-for animate objects, which is inserted between the root and the pronominal affix:

(36) Ná-vóósáne.

(1)-see.AI

'I see.'

(37) Ná-vóóht-a momóhtỏxe'áxestòtse.

(1)-see.TI-1:I film

'I see / am seeing a film.'

(38) Ná-vóóm-o na’èstse hetane.

(1)-see.TA-1:3 one man

'I see / am seeing one man.'

${ }^{18}$ More examples will be provided in table 9, page 409 .

Acta Linguistica Hungarica 61, 2014 
Regarding the order of the two core arguments, as mentioned above, word order in Cheyenne is pragmatically conditioned and, consequently, the basic order of constituents is very flexible since it is frequently altered for pragmatic reasons:

(39) Vého'e na'èstse ésevono é-ná h-ó-ho.

white.man one female.buffalo (oBv) (3)-kill.TA-3:4-SG.A+4.P

'The white man killed a buffalo.'

(40) Na'èstse ésevono vého'e é-ná h-ó-ho.

one female.buffalo (oBV) white.man (3)-kill.TA-3:4-SG.A+4.P

'The white man killed a buffalo.'

As can be deduced, word order in Cheyenne is not so crucial for the assignment of syntactic functions, since the rich morphology of both the verb and the noun, or more specifically in this case, the marking of obviation in the noun, prevents ambiguity: in the two former examples, despite the fact that the order of the two obligatory arguments of the predicate has been exchanged, we can see which NP stands for the subject and which for the object owing to the grammatical information provided by both the verbal agreement markers. Furthermore, the information provided by the verbal suffix -óho reinforces this view since it specifies very clearly that the third person participant vé'ho'e is the subject and the obviated constituent na'estse ésevono is the object.

\subsection{Three-place predicates}

Finally, we have predicates that require three core arguments. According to Wolvengrey $(2011,152)$, there seems to be a general rule in Algonquian languages by which TA verbs can have two or three participants, but only two of the referents are marked. For example, in Ojibwa (Dryer 1986, 842) the verbal paradigm for ditransitive constructions ${ }^{19}$ presents systems of object affixes on verbs varying according to the Recipient $(\mathrm{R})$ rather than the Theme $(\mathrm{T})$, something that seems to reflect the fact that the latter is not coded in the verb. Dryer states that this is not surprising, given that Rs are likely to vary in terms of person, while Ts in these constructions are generally inanimate, so that it makes more sense functionally for the verb

${ }^{19}$ Like Primus (1999), I will use the term "ditransitive" in purely semantic terms to refer to a three-argument construction that consists of a (ditransitive) verb, an agent argument, a recipient-like argument, and a theme argument. 
in a ditransitive clause to code the person of the $\mathrm{R}$ rather than the person of the $\mathrm{T}$, since the latter is generally more predictable. In addition, in Blackfoot (Russell et al. 2012), ditransitive verb stems show cross-reference with, at most, two participants, namely the A and the T, R or Beneficiary (B), depending on the specific stem in question. Regarding Cheyenne, the assumption that only two referents are coded by ditransitive verbs also appears to be true and, as can be seen in (41), some of its three-place predicates give preference to the $\mathrm{A}$ and $\mathrm{R}$ over the $\mathrm{T}$ :

(41) Né-het-ȧtse kảsovaahéso tsé-heše-pèhévae-se.

(1)-tell.TA-1:2 boy CLM-REL-be.good.AI-3

'I told you that the boy is good.'

The preference of the predicate het 'tell' for only two participants (the two animate ones) is especially reflected in the final agreement marker -atse, which in turn reflects the fact that a first-person singular participant transmits a message to a second-person participant. Taking this into account, it seems plausible to argue that ditransitive verbs in Cheyenne behave like TA verbs.

Nevertheless, there are many other verbs, such as the stems mét 'give to', véestomev 'ask for', éestsesstomev 'speak about to', nomáhtseh 'steal from', véstomev 'promise', or vóo 'seh 'show' that behave like true ditransitive verbs, since they appear to cross-reference the three core arguments morphologically:

(42) Né-mét-o-no-vo mo’éhno'hāme.

(2)-give.DITR-2:33:4-4.T-33.R horse (oBV)

'You gave them a horse.'

(43) Né-tavánne-véestomev-atse-nò-(o)tse mảhtohto?

(2)-may-ask.for.DITR-1:2:II-II.T-II.T ten.dollars

'May I borrow 10 dollars from you?' (lit. 'May I ask you for ten dollars?')

(Fisher et al. 2006, 293)

(44) Ná-véstomev-ó-no-to he'oho.

(1)-promise.DITR-1:3:4-4.T-SG.A+3.R+4.T woman (OBV)

'I promised him a woman/wife.'

In order to find out if these predicates mark their three core arguments or only two of them, it seems to be necessary to compare the form of the agreement markers shown by TI (table 4) and TA (table 12 in the 
Appendix) verbal paradigms with that of agreement markers of ditransitive verbs (tables 13, 14, 15 and 16 in the Appendix):

Table 6: Comparison between TI, TA and DITR paradigms in terms of their agreement markers

\begin{tabular}{lllll}
\hline & $\begin{array}{l}\text { DITR. } \\
\text { (Inan.sing. theme) }\end{array}$ & $\begin{array}{l}\text { DITR. } \\
\text { (Inan.pl. theme) }\end{array}$ & $\begin{array}{l}\text { DITR. } \\
\text { (Anim.sg. theme) }\end{array}$ & $\begin{array}{l}\text { DITR. } \\
\text { (Anim.pl. theme) }\end{array}$ \\
\hline TI (sing. patient) & $1 / 50=2 \%$ & $0 / 50=0 \%$ & $0 / 50=0 \%$ & $0 / 50=0 \%$ \\
TI (pl. patient) & $0 / 50=0 \%$ & $0 / 50=0 \%$ & $0 / 50=0 \%$ & $0 / 50=0 \%$ \\
TA & $21 / 50=42 \%$ & $0 / 50=0 \%$ & $12 / 50=24 \%$ & $8 / 50=16 \%$ \\
\hline
\end{tabular}

As can be deduced from table 6 above, we can see that, except for some coincidences, mainly between the TA paradigm and the ditransitive with an inanimate singular $\mathrm{T}$ paradigm and between the TA paradigm and the ditransitive with an animate singular T paradigm, where nearly half (42\%) and approximately a quarter of forms (24\%) are identical respectively, all these verbal paradigms differ greatly, as can be illustrated in the examples below:

(45) Né-met-atsé-no-vó-(o)tse na-maahótse.

(2)-give.DITR-1:22:II-II.T-22.R-II.T my-arrows

'I give you (pl.) my arrows.'

(46) Ná-pèhévan-a-nò-(o)tse na-maahe.

(1)-fix.TI-1:II-II.P-II.P my-arrows

'I fix my arrows.'

(47) Né-vóom-atsē-me.

(2)-see.TA-1:22-1.A+22.P

'I see you (pl.).'

Examples (45)-(47) include a ditransitive, a TI and a TA stem respectively and, as we can see, the ditransitive suffix -atsénovótse appears to mark the three participants required semantically by its predicate, namely a first person singular $\mathrm{A}$, a second person plural $\mathrm{R}$ and an inanimate plural $\mathrm{T}$, since its form is different from both the TI agreement marker -anotse, which indexes a first person singular $\mathrm{A}$ and an inanimate plural $\mathrm{P}$, and the TA agreement marker -atsemene, which cross-references a first person singular A and a second person plural direct $\mathrm{P}$. The fact that the different verbal paradigms that ditransitive verbs show are so different from both the TI and TA verbal paradigms appears to provide strong evidence to 
claim that the agreement markers must index something other than two participants, that is to say, something that indicates that an extra participant is involved in the action, which leads us to claim that the three participants are marked on the verb via indexation. This is, thus, different from other Algonquian languages, since in most of them the addition of a third participant in ditransitive constructions has no effect whatsoever on the inflectional morphology of a monotransitive verb. It can therefore be assumed that the three core arguments, and not only two of them, are coindexed by the pronominal affixes in these verbs.

After the presence of agreement markers for the three obligatory arguments in a ditransitive construction has been borne out, the remainder of this section will be devoted to an examination of the ditransitive verbal paradigm and an analysis of other types of three-argument constructions, namely locative, benefactive and causative constructions.

Ditransitive verbs exhibit a very complex system of suffixes, which vary with respect to the animacy and number of the participant playing the semantic role of theme. Consequently, there will be four different paradigms for ditransitive verbs according to the different grammatical features of the element functioning as theme in the construction. Appendix 2 provides a table that includes the paradigm for the most common ditransitive construction, where the Agent (A) and the Recipient (R) are animate but the Theme $(\mathrm{T})$ is an inanimate singular thing; then the table included in Appendix 3 shows a ditransitive construction consisting of an animate $\mathrm{A}$, an animate $\mathrm{R}$, and an inanimate plural $\mathrm{T}$; next, the table in Appendix 4 presents the ditransitive construction that includes an animate $\mathrm{A}$, an animate $\mathrm{R}$, and an animate singular $\mathrm{T}$; and finally, the table in Appendix 5 deals with the ditransitive construction where the $\mathrm{A}$ and the $\mathrm{R}$ are animate and the $\mathrm{T}$ is animate plural.

On the other hand, as we can see throughout these charts, despite the rich morphology exhibited by ditransitive verbs, whose suffixes carry a great amount of grammatical information in terms of person, number, animacy, salience and syntactic function, the three obligatory arguments are not always accurately specified, which implies that there can sometimes be some ambiguity in this type of construction:

$$
\text { Né-mét-o-no-vo mo'éhno'hāme. }
$$

a. (2)-give.DITR-2:33:4-4.T-33.R horse (OBV)

'You gave them a horse.'

b. (2)-give.DITR-22:3:4-4.T-22.A horse (OBV)

'You (pl) gave him/her a horse.' 
c. (2)-give.DITR-22:33:4-4.T-22.A/33.R horse (OBV)

'You (pl) gave them a horse.'

Furthermore, this ambiguity might be even greater if we bear in mind that there is no difference in number in the obviated element:

$$
\text { Né-mét-o-no-vo mo’éhno’hāme. }
$$

d. (2)-give.DITR-2:33:4-4.T-33.R horse (OBV)

'You gave them horses.'

e. (2)-give.DITR-22:3:4-4.T-22.A horse (OBV)

'You (pl) gave him/her horses.'

f. (2)-give.DITR-22:33:4-4.T-22.A/33.R horse (OBV)

'You (pl) gave them horses.'

Ditransitive constructions are the most typical three-argument constructions but there are other constructions that, although they do not match the agent-recipient-theme pattern and, consequently, they are not coded as ditransitive, also include three arguments. One example is provided by the locative construction involving the English predicate 'put', which also includes three obligatory arguments, namely an $\mathrm{A}$, a $\mathrm{P}$ and a locative (LOC):

(49) É-s-táho'ts-é-no-vò-(o)tse héne mỏxe’èstoo'o táxemésèhéstó(tse)-va.

(3)-PAST-put.TI-33:I-II.P-33.A-II.P DEIC book table-LOC

'They put that book on the table.'

The Cheyenne predicate táho'tsé 'put' also requires three obligatory core arguments and, as in English, two of these arguments (e.g., the agent and the patient) are realized as direct core arguments and one of them (e.g., the locative) is an oblique core argument marked by a locative suffix. Consequently, the verbal suffix -énovotse only codes two arguments, an animate $\mathrm{A}$ and an inanimate $\mathrm{P}$, but does not reflect the presence of any marker representing the $\mathrm{L}$, despite the fact that this element is required by the predicate. Thus, a noun expressing location co-occurs with an A and a $\mathrm{P}$, hence the verb reflects the TI paradigm, that is, it exhibits an instance of a simple monotransitive construction.

Another example of a three-argument construction is the benefactive construction involving the presence of an argument that is a beneficiary of the action described by the verb: 
(50) Ná-manèstóotāh-o-nò-(o)tse hétóhe mo’kèhanòtse.

(1)-make.for.BEN.TA-1:3:II-II.T-II.T DEIC moccasins

'I made these moccasins for him.'

The Cheyenne verb to render 'make something for somebody' is manèstóotah, which is composed of the TI verb manestsé meaning 'make something' plus the final applicative particle -omotah, which signals the beneficiary of the action. Unlike other Algonquian languages, the benefactive construction in Cheyenne cross-references all three participants, ${ }^{20}$ that is the A, the P, and the B. By contrast, Wolvengrey $(2011,145)$ states for Plains Cree - another Algonquian language - that this language gives preference to animate over inanimate participants and, therefore, that these predicates behave like TA verbs since they only code the two highest ranking participants, leaving the $\mathrm{T}$ unmarked. Nevertheless, although it appears to be an exceptional situation, the fact that this predicate 'make' semantically requires a $\mathrm{T}$, and that this is represented by a specific participant, makes it possible for it to be marked on the verb. Consequently, it seems plausible to claim that the benefactive construction is a transitivity-increasing process.

Finally, another type of three-argument construction is illustrated by causative verbs, which involves the presence of an argument that is a causee of the action described by the verb:

(51) Ná-vóo-'sèh-ae-no-to he-stónaho ${ }^{21}$

(1)-see-CAUS.DITR-3:1:4-4.T-3.A+4.T his-daughter (OBV)

'He showed me his daughter.'

As we can see in (51) the verbal suffix - aenoto $^{22}$ reflects the fact that the three participants, that is third person singular causer, a first person singular causee and an animate $\mathrm{P}$ of the caused event, are marked, which leads to the assumption that the addition of the causative final stem -'seh

${ }^{20}$ On the one hand, the TI verbal stem is manestsé 'make something' and its corresponding forms to 'I make it' and 'I make them' are: ná-manēstse and námanēstsenotse (cp. TI (pl)-enotse vs. BEN -onotse). On the other hand, the TA verbal stem is maneh 'make someone' and the corresponding expression to 'I make him' is é-manéhóho.

21 The nominal stem is htona 'daughter'.

22 This agreement marker can be compared with (a) - a/e, the verbal suffix that marks the presence of an animate subject and an inanimate object in a TI stem, and (b) $-a(e)$, the verbal suffix that indicates the presence of an animate subject and an animate object. 
makes the verbal stem ditransitive and therefore that this situation also reflects a transitivity-increasing process.

In summary, both beneficiary and causative constructions provide an important source for predicates marking three core arguments, leading us to the assumption that, except for locatives, whose oblique element is not marked on the verb, all types of three-place predicates in Cheyenne crossreference all their three core arguments.

\section{Ditransitive alignment in Cheyenne}

The study of ditransitive verbs has long been a challenging issue owing to the number of arguments coded by the verb, the type of marking shown by the arguments, the possible existence of alternations and splits, and the pattern of alignment shown by them.

The concept of alignment ${ }^{23}$ captures the way in which the encoding of transitive and ditransitive constructions differs across languages. Haspelmath (2005) claims that, by analogy with monotransitive alignment, there are three major ditransitive alignment types in terms of the encoding of $\mathrm{T}$ and $\mathrm{R}$ compared to the monotransitive Patient $(\mathrm{P})$ : direct-indirect object pattern or indirective alignment, where the $\mathrm{T}$ is identified with the $\mathrm{P}$ in contrast to the $\mathrm{R}$, primary-secondary object pattern or secundative alignment, where the $\mathrm{R}$ is identified with the $\mathrm{P}$ while the $\mathrm{T}$ is distinct, and neutral alignment, where the $\mathrm{P}, \mathrm{T}$, and $\mathrm{R}$ are all treated the same. There are two more minor patterns referred to as tripartite, in which the $\mathrm{T}$ and the $\mathrm{R}$ differ from the $\mathrm{P}$ and from each other, and double oblique/horizontal, in which the $\mathrm{T}$ and the $\mathrm{R}$ are coded in the same way, but differently from the P. However, both are uneconomical and hence rare.

These ditransitive alignment patterns can be determined in terms of both coding criteria, namely flagging (case and adpositional marking), indexing (person(-number) agreement or cross-referencing/verb coding), or word order, and behavioural criteria, such as passivization, nominalization, noun incorporation, relativization, the formation of constituent questions, reflexivization, reciprocalization, or direct-inverse marking. These syntac-

${ }^{23}$ Planck $(1979,4)$ seems to have been the first to use the term "alignment" to indicate the way the arguments are coded in monotransitive ergative and accusative constructions in a language, although since then it has also been extended to refer to the comparison of the properties of arguments between monotransitive and ditransitive constructions (Siewierska 1996; Haspelmath 2005; Bickel \& Nichols 2009, among others). 
tic phenomena offer insights concerning the differential status of ditransitive objects and, consequently, they help us deduce which is the argument, $\mathrm{T}$ or $\mathrm{R}$, functioning as the monotransitive $\mathrm{P}$ in a ditransitive construction.

\subsection{Coding criteria:}

Coding criteria, that is flagging, indexing, and word order, are considered the primary means of argument coding. Bearing in mind the fact that both $\mathrm{Rs}$, as in (52), and Ts, as in (53), can receive obviative case marking and, consequently, no argument is marked distinctly, it seems plausible to argue that Cheyenne shows neutral flagging:

(52) Né-mét-ae-no-to ma'xemeno.

(2)-give.DITR-3:2:4-4.T-3.A+4.T apple (OBV)

'She gave me an apple.'

(53) É-mét-ó-ho he-méèševotamo.

(3)-give.DITR-3:4:I-SG.A+4.R+I.T her-baby (OBV)

'She gave it to her baby.'

Regarding indexing, it is very easy to find out which of the two non-agent participants behaves like the monotransitive patient since the ditransitive verbal paradigms are more similar to their TA than TI counterparts, especially in the form of their theme suffixes (i.e., alternating suffixes; Russell 1987), which mark either direct or inverse direction (table 7).

As discussed above, Cheyenne ditransitive verbs are marked for both the $\mathrm{R}$ and $\mathrm{T}$. As can be observed in table 7 , the different ditransitive verbal paradigms show the same theme suffixes as the TA paradigm, regardless of the animacy and number of the $\mathrm{T}$. This means that $\mathrm{R}$ is the primary object, which is always animate, since it behaves analogously as P. Furthermore, in order to complete their agreement, ditransitive verbs show other suffixes (see table 8) that carry information about the A, R, and T, which becomes the secondary object. Consequently, given $\mathrm{P}$ is identified with $\mathrm{R}$, in contrast to $\mathrm{T}$ in ditransitive constructions, it is plausible to claim that this construction exhibits secundative alignment.

According to Primus (1998) and Siewierska \& Bakker (2007), the ordering of nominal objects in ditransitive constructions appears to be ruled by a small set of principles, such as prominence, weight, or iconicity. When it comes to analysing the order of full NPs in Cheyenne ditransitive constructions, we must bear in mind that, as mentioned in section 2, the word order exhibited by the sentence constituents in Cheyenne may vary for 
Table 7: Comparison of theme suffixes in TI, TA and DITR paradigms

\begin{tabular}{|c|c|c|c|c|c|}
\hline agreement & $\begin{array}{c}\text { DITR } \\
(\mathrm{I}) \\
\text { agreement }\end{array}$ & $\begin{array}{c}\text { DITR } \\
\text { (II) } \\
\text { agreement }\end{array}$ & $\begin{array}{c}\text { DITR } \\
\text { (AN.SG.) } \\
\text { agreement }\end{array}$ & $\begin{array}{c}\text { DITR } \\
\text { (INAN.PL) } \\
\text { agreement }\end{array}$ & Context \\
\hline $\begin{array}{l}\text { e.g., (1-22) } \\
\text {-atse-me }\end{array}$ & $\begin{array}{l}\text { e.g., }(1-22-\mathrm{I}) \\
\text {-atse-0 }\end{array}$ & $\begin{array}{l}\text { e.g., }(1-22-\mathrm{II}) \\
\text {-atse-novotse }\end{array}$ & $\begin{array}{l}\text { e.g., }(1-22-3) \\
\text {-atse-novo }\end{array}$ & $\begin{array}{l}\text { e.g., }(1-22-33) \\
\text {-atse-novoo'o }\end{array}$ & $\begin{array}{l}\text { INVERSE } \\
\text { Local scenario: } \\
\text { 1/11:2/22 }\end{array}$ \\
\hline $\begin{array}{l}\text { e.g., (3-11) } \\
\text {-ae-ne }\end{array}$ & $\begin{array}{l}\text { e.g., }(3-11-\mathrm{I}) \\
\text {-ae-none }\end{array}$ & $\begin{array}{l}\text { e.g., (3-11-II) } \\
\text {-ae-nonestse }\end{array}$ & $\begin{array}{l}\text { e.g., (3-11-4) } \\
\text {-ae-none }\end{array}$ & $\begin{array}{l}\text { e.g., (3-11-44) } \\
\text {-ae-none }\end{array}$ & $\begin{array}{l}\text { INVERSE } \\
\text { Mixed scenario: } \\
\text { 3/4:1/2/11/12/22 } \\
\end{array}$ \\
\hline $\begin{array}{l}\text { e.g., (11-33) } \\
\text {-o-neo'o }\end{array}$ & $\begin{array}{l}\text { e.g., }(11-33-\mathrm{I}) \\
\text {-o-none }\end{array}$ & $\begin{array}{l}\text { e.g., (11-33-II) } \\
\text {-o-nonestse }\end{array}$ & $\begin{array}{l}\text { e.g., (11-33-4) } \\
\text {-o-none }\end{array}$ & $\begin{array}{l}\text { e.g., }(11-33-44) \\
\text {-o-novo }\end{array}$ & $\begin{array}{l}\text { (a) DIRECT } \\
\text { Mixed scenario: } \\
\text { 1/2/11/12/22:3/33/4 }\end{array}$ \\
\hline $\begin{array}{l}\text { e.g., (3-4) } \\
\text {-o-ho }\end{array}$ & $\begin{array}{l}\text { e.g., (3-4-I) } \\
\text {-o-ho }\end{array}$ & $\begin{array}{l}\text { e.g., }(3-4-\mathrm{II}) \\
\text {-o-notse }\end{array}$ & $\begin{array}{l}\text { e.g., }(3-4-5) \\
\text {-o-noto }\end{array}$ & $\begin{array}{l}\text { e.g., }(3-4-55) \\
-o \text {-noto }\end{array}$ & $\begin{array}{l}\text { (b) DIRECT } \\
\text { Non-local scenario: } \\
3: 4\end{array}$ \\
\hline $\begin{array}{l}\text { e.g., }(2-1) \\
-e-0\end{array}$ & $\begin{array}{l}\text { e.g., (2-1-I) } \\
-e-0\end{array}$ & $\begin{array}{l}\text { e.g., }(2-1-\mathrm{II}) \\
-e \text {-notse }\end{array}$ & $\begin{array}{l}\text { e.g., (2-1-3) } \\
-e \text {-notse }\end{array}$ & $\begin{array}{l}\text { e.g., }(2-1-33) \\
-e \text {-noto }\end{array}$ & $\begin{array}{l}\text { (a) DIRECT } \\
\text { Local scenario: } \\
\text { 2/22:1/11 }\end{array}$ \\
\hline $\begin{array}{l}\text { e.g., }(\mathrm{X}-1) \\
\text {-an-e- } 0\end{array}$ & $\begin{array}{l}\text { e.g., }(\mathrm{X}-1-\mathrm{I}) \\
\text {-an-e- } 0\end{array}$ & $\begin{array}{l}\text { e.g., }(\mathrm{X}-1-\mathrm{II}) \\
\text {-an-e-notse }\end{array}$ & $\begin{array}{l}\text { e.g., }(X-1-3) \\
\text {-an-e-notse }\end{array}$ & $\begin{array}{l}\text { e.g., }(X-1-33) \\
\text {-an-e-noto }\end{array}$ & $\begin{array}{l}\text { (b) INVERSE } \\
\text { Mixed/Non-local } \\
\text { scenario: X:? }\end{array}$ \\
\hline
\end{tabular}

pragmatic reasons, which makes the distinction between the arguments in terms of alignment much more difficult to discern:
(54) a. Tséhéhéto ${ }^{24}$ é-mét-ó-ho móxe'èstoo'o tséheváseméto. ${ }^{25}$ my.father
(4)-give.DITR-4:5:I-SG.A+5.R+I.T book my.brother 'My father gave the book to my brother./My father gave my brother the book.'
b. Tséhéhéto é-mét-ó-ho tséheváseméto mỏxe'èstoo'o. my.father (4)-give.DITR-4:5:I-SG.A+5.R+I.T my.brother book 'My father gave the book to my brother./My father gave my brother the book.'

In principle, given an appropriate context, any ordering pattern is acceptable, but, even so, this variation must not be regarded as an example of alternation since the different position of the two object NPs simply modifies the pragmatic focus of the sentence, without affecting the syntactic and semantic properties of the arguments. Thus, although the position of the NP arguments may vary, the form of the affix remains the same.

24 The expression tséhéhéto is indeed a participial verbal form in the Conjunct Order formed by the complementizer tsé-, the preverbal particle -he-indicating possession, a verbal stem derived from the animate noun stem -héh 'father', and the agreement marker -to.

25 The same as above in the previous footnote, with the exception of the nominal predicate, since in this case the verbal stem derives from the animate noun stem -vásem meaning 'younger sibling'. 
According to Leman (1991, 37), Cheyenne appears to have a tendency to place the newsworthy information (any element expressing a contrast, introducing or changing a topic, or representing new information) preverbally (i.e., to the left) and inferable or evoked information postverbally (i.e., to the right) $:^{26}$

(55) Tséhéhéto mòxe'èstoo'o é-hohtovoota-ó-ho tsé-he-axaa'éhémeto. my.father book (3)-buy.BEN.DITR-3:4:I-SG.A+4.B+I.T his-sister

'My father bought a book for my sister.'

It is generally assumed that the $\mathrm{T}$ participant - prototypically third person, nonhuman, and indefinite - is usually more topical than the $\mathrm{R}$ argument - prototypically first/second person, human, and definite. However, in Cheyenne, owing to the great variety exhibited by Ts in terms of animacy and number, and the restriction that Rs can only be animate, Ts are less topical than Rs. This would account for the fact that, despite the apparent freedom of the constituents in this language, my native consultants, when faced with the elicitation of examples of ditransitive constructions, tend to provide the same translation, being biased to the word order $\mathrm{T}+\mathrm{R},{ }^{27}$ especially in situations potentially leading to ambiguity:

(56) a. Néhe hēée é-vóo'seh-ó-no-to

DEIC woman (3)-see.CAUS.DITR-3:4:5-5.T-3.A/4.R+5.T

he-mé'èševotamo he-vésenóho.

her-baby (OBV) her-friend (OBV)

'This woman showed her friend to her baby'

b. Néhe hēée é-vóo'seh-ó-no-to

DEIC woman (3)-see.CAUS.DITR-3:4:5-5.T-3.A/4.R+5.T

he-vésenóho he-mééššvotamo.

her-friend (OBV) her-baby (OBV)

'This woman showed her baby to her friend.'

${ }^{26}$ Although, in terms of information structure, it is cross-linguistically more common to place the most topical participants to the left than to the right of the sentence, Rhodes $(2010,638)$ also states for Ojibwa that "the most topical arguments appear furthest to the right".

27 This situation may also be due to the influence of the factor of iconicity, which reflects the temporal ordering of speech events, and consequently, the $\mathrm{T}$ appears to be more prominent than the $\mathrm{R}$ in this respect when they are represented by NPs (Dik 1997). On the other hand, my native consultants also appear to alter the order of the two NPs depending on their weight. Accordingly, they tend to place light-constituents closer to the verb than heavy-constituents, especially when the latter are complemented by a relative clause. 
The same situation appears to apply to other three-argument constructions, as can be seen in the following example of a benefactive construction:

(57) Tséheškéto ${ }^{28}$ é-honóht-omotảh-ó-ho

my.mother (4)-bake-BEN.DITR-4:5:I-SG.A+5.B +I.T-4.A

vé'keahonoo'o tséheváseméto.

cake my.brother

'My mother baked my brother a cake./My mother baked a cake for my brother.'

In summary, taking into account the fact that Ts tend to precede Rs in ditransitive constructions leads to the assumption that this language exhibits indirective alignment in terms of the word order of constituents. This situation is, nevertheless, exceptional since sentences with more than one NP are extremely rare in natural discourse, and consequently, it must not be taken as an exception to the apparent tendency for NP IOs to precede NP ODs crosslinguistically when both are unmarked by preposition or distinctive case (Blansitt 1973, 14; Faltz 1978, 82; Primus 1998, 438-439).

According to Gensler $(2003,217)$ the relative order of object-morphemes in ditransitive constructions does not show any crosslinguistically uniform pattern. More specifically, in Cheyenne, owing to the complex morphology exhibited by their verbs, reflected in the fact that Cheyenne verbal affixes do not simply consist of a combination of pronominal affixes corresponding separately to the A, T, and R arguments, it is very difficult to analyse separately the coding of the two arguments $\mathrm{T}$ and $\mathrm{R}$, and consequently the possibility of noticing a preference for any specific pattern in terms of the ordering of bound forms (i.e., non-alternating suffixes; Russell 1987) in this language may be merely tentative (table 8 ).

The fact that these bound forms can therefore be considered as portmanteau forms where the different markers representing the grammatical relationships existing between the arguments are fused into single morphs and that verbal suffixes occur in a strictly fixed order (i.e., tse-me-no-ne$v o / t s e / o^{\prime} o$ ) appears to indicate that there exists no special preference for one argument over the other with respect to ordering.

However, by comparing the indexing patterns in table 8, we could perhaps notice that the $\mathrm{R}$ bound forms are a slightly closer to the verbal stem than the $\mathrm{T}$ bound forms, which seems to suggest secundative

28 The same as above in footnote 24 with the exception of the nominal predicate, since in this case the verbal stem comes from the animate noun heške meaning 'mother'. 
Table 8: Ordering patterns of ditransitive verbal suffixes in the Independent Order

\begin{tabular}{|c|c|c|}
\hline Ordering pattern & Context & Indexing \\
\hline $\begin{array}{l}\text { E.g., me - no } \\
(11-2-\mathrm{I})\end{array}$ & $2 / 11 / 22+2 / 11 / 22+?\}-\left\{\begin{array}{l}\text { PL.A+? + I } \\
?+\text { PL.R + I }\end{array}\right.$ & $\mathrm{A} / \mathrm{R}-\mathrm{A} / \mathrm{R} / \mathrm{T}$ \\
\hline $\begin{array}{l}\text { E.g., no - vo } \\
\qquad(33-22-I)\end{array}$ & $\left.\begin{array}{l}\text { PL.A+?+I } \\
?+P L . R+I\end{array}\right\}-\left\{\begin{array}{l}?+22 / 33+? \\
22 / 33+?+?\end{array}\right.$ & $\mathrm{A} / \mathrm{R} / \mathrm{T}-\mathrm{A} / \mathrm{R}$ \\
\hline $\begin{array}{l}\text { E.g., tse - no - ne - (s)tse } \\
\qquad(4-11-\mathrm{II})\end{array}$ & $\left.\begin{array}{l}4+1 / 11 / 12+? \\
4+2 / 22+?\end{array}\right\}-\left\{\begin{array}{l}?+?+\mathrm{II} \\
\}\end{array}\right\}-\left\{\begin{array}{l}11 / 12+?+? \\
?+11 / 12+?\end{array}\right\}-\{?+?+\mathrm{II}$ & A/R-T- A/R-T \\
\hline $\begin{array}{l}\text { E.g., tse - no - vo - tse } \\
(4-22-\mathrm{II})\end{array}$ & $\left.\begin{array}{l}4+1 / 11 / 12+? \\
4+2 / 22+?\end{array}\right\}-\left\{\begin{array}{l}?+?+\mathrm{II} \\
\}\end{array}\right\}-\left\{\begin{array}{l}22 / 33+?+? \\
?+22 / 33+?\end{array}\right\}-\{?+?+\mathrm{II}$ & $\mathrm{A} / \mathrm{R}-\mathrm{T}-\mathrm{A} / \mathrm{R}-\mathrm{T}$ \\
\hline $\begin{array}{l}\text { E.g., tse - no - to } \\
(4-4-5)\end{array}$ & $\left.\begin{array}{l}4+1 / 11 / 12+? \\
4+2 / 22+?\end{array}\right\}-?+?+3 / 4 / 5-$ SG.A+3/4+4/5 & $\mathrm{A} / \mathrm{R}-\mathrm{T}-\mathrm{A} / \mathrm{R} / \mathrm{T}$ \\
\hline $\begin{array}{c}\text { E.g., no - ne - o'o } \\
(33-12-4)\end{array}$ & $?+?+3 / 4 / 5-\left\{\begin{array}{l}?+11 / 12+? \\
11 / 12+?+?\end{array}\right\}-\left\{\begin{array}{l}33+\text { PL.R+4 } \\
\end{array}\right.$ & T- A/R - A/R/T \\
\hline $\begin{array}{l}\text { E.g., no - vo - o'o } \\
\qquad(33-22-44)\end{array}$ & $?+?+33 / 44 / 55-\left\{\begin{array}{l}?+22 / 33+? \\
22 / 33+?+?\end{array}\right\}-\left\{\begin{array}{l}33+P L . R+44 \\
\text { PL.A+?+33 } \\
?+P L . R+33\end{array}\right.$ & T-A/R-A/R/T \\
\hline
\end{tabular}

indexing. This would confirm the assumption that, when both $\mathrm{T}$ and $\mathrm{R}$ are unflagged, the $\mathrm{R}$ generally precedes the $\mathrm{T} .{ }^{29}$ This assumption appears to derive from the fact that $\mathrm{R}$ is generally more animate and often more definite than the $\mathrm{T}$ (Malchukov et al. 2010, 16), making this ordering functionally preferred owing to the prominence of the human-nonhuman and definite-indefinite order of elements. ${ }^{30}$

Taking into account both types of ordering, namely in terms of both bound and free forms, it seems plausible to argue that the "mirror-image pattern" posited by Primus $(1998,439 ; 471)$, whereby the ordering of affixes/clitics is the mirror-image of the ordering of full NPs, is not found in Cheyenne. Given that it is a pronominal-argument language and that, consequently, pronominal clitics occupy argument positions, it seems reasonable to claim that the ordering of bound forms has preference over that of full NPs, which leads us to highlight the importance of the concepts of animacy and specificity in this language.

${ }^{29}$ Gensler $(2003,201)$ posits that, although the IO-DO ordering could be deemed, in functional terms, the "most natural" order, there is no indication that this ordering is favoured crosslinguistically.

${ }^{30}$ Zwicky $(1977,25)$ also states that this is a frequent pattern for clitics. 
The referential factor of specificity plays an important role in Cheyenne since it affects the transitivity of a verb and may, consequently, influence the alignment pattern. Thus, the Cheyenne equivalents of predicates such as 'give', 'ask for/borrow', 'tell', 'steal', or 'bake', are intransitive, monotransitive, or ditransitive predicates depending on the specificity of their arguments since they vary the form of their stem according to the number of arguments they cross-reference (table 9).

Table 9: Effect of specificity on transitivity

\begin{tabular}{lllll}
\hline Verb stem & AI & TI & TA & DITR \\
\hline -mé- 'give' & mea'e & mea'e & méa'tov & mét \\
-véest- 'ask for, borrow' & véestono'he & véestá & véestan & véestomev \\
-éest- 'tell, speak' & éestse & éestsétá & éestsėstov & éestsėstomev \\
-nomáht- 'steal' & nomáhtsé & nomáhtsé & nomáhtsétov & nomáhtseh \\
\hline
\end{tabular}

AI stems are used with one argument indexed on the verb, TI and TA stems are used with two arguments indexed on the verb, differing as to the gender of the primary object, and ditransitive stems cross-reference three arguments. Consequently, the referential factor of specificity plays a significant role in the marking of arguments in ditransitive constructions since the specificity of the arguments governs the choice between the indexing of A, A plus T and A plus R in AI, TI and TA stems, as can be seen in the following examples including the predicate méa é 'give':

(58) É-méa-o’o.

(3)-give.AI-33

'They give.'
(59) É-méáe hé-stáme ${ }^{31}$ vo èstanóho.

(3)-give.Tı.3:I his-food people

'He gives his food to people.'

(60) É-méa-no-to mahpe.

(3)-give.TA-3:4.4.R-3.A+4.R water

'He gives him water.'

(61) Né-mét-am-ó-no-to mo’éhno'hāme naka'èškónèhamo. (2)-give.DITR-4.R-2:4:5-5.T-4.R+5.T horse (OBV) my.children (OBV) 'You gave them a horse.'

31 The addition of the suffix he- 'his' to the word htáme 'food' provokes a modification in the first consonant. 
In examples (58)-(61), the clauses include non-specific participants, which are not indexed on the verb 'give'. For example, in (58) both the T and $\mathrm{R}$ are absent from the clause and consequently the verbal form presents an AI stem. Likewise, although both the $\mathrm{R}$ in (59) and the $\mathrm{T}$ in (60) are present in the clause, they do not refer to specific participants and are not coindexed by the verbal agreement marker either. Unlike these examples, in (61) all three participants are specific and, consequently, are indexed on the verb, as can be seen in the form of the agreement markers.

Likewise, this situation appears to confirm that alignment types should be associated with particular constructions, rather than with entire languages because, although in the simplest case a language has just a single ditransitive construction, some languages show more than one. For instance, the Cheyenne predicate meaning 'give' can cross-reference different arguments and consequently exhibits different alignment patterns in terms of indexing depending on the specificity of its referents (table 10).

Table 10: Splits exhibited by the Cheyenne predicate mé- 'give'

\begin{tabular}{|c|c|c|c|}
\hline Predicate & Stem & Cross-referenced participants & Meaning \\
\hline -méa'e- & AI & Agent & $\begin{array}{l}\text { 'give something (non-specific) to } \\
\text { someone (non-specific)', e.g., (58) }\end{array}$ \\
\hline -méa'e- & TI & Agent, Theme & $\begin{array}{l}\text { 'give something to someone (non- } \\
\text { specific', e.g., (59) }\end{array}$ \\
\hline -méa'tov- & TA & Agent, Recipient & $\begin{array}{l}\text { 'give something (non-specific) to } \\
\text { someone', e.g., (60) }\end{array}$ \\
\hline -mét- & DITR & Agent, Recipient, Theme & $\begin{array}{l}\text { 'give something to someone', e.g., } \\
(61)\end{array}$ \\
\hline
\end{tabular}

The root -mé- combines with abstract AI, TI, TA and DITR finals to create stems meaning 'give', as shown in table 10 and in examples (58)-(61). Depending on the specificity of the referents involved, the stem méa'e may present two alternatives since it can index either no argument or the $\mathrm{T}$, which becomes the primary object. In contrast, the stem méa tov presents an irregular inflectional paradigm which codes only the R, which becomes the primary object. Finally, the ditransitive stem mét cross-references its three obligatory arguments in a construction that appears to give preference to the $\mathrm{R}$ over the $\mathrm{T}$ and, consequently, appears to favour secundative alignment. 


\subsection{Behavioural criteria}

Besides the coding criteria, we can also establish the alignment type for ditransitive constructions by analysing the properties the $\mathrm{T}$ and $\mathrm{R}$ arguments show in other constructions, such as passivization, nominalization, noun incorporation, relativization, the formation of constituent questions, reflexivization, reciprocalization, or direct-inverse marking.

As mentioned above, Cheyenne does not exhibit the typical Englishlike passive construction and its closest equivalent, the Unspecified Agent construction, does not offer us any evidence to differentiate between the properties of the two objects:

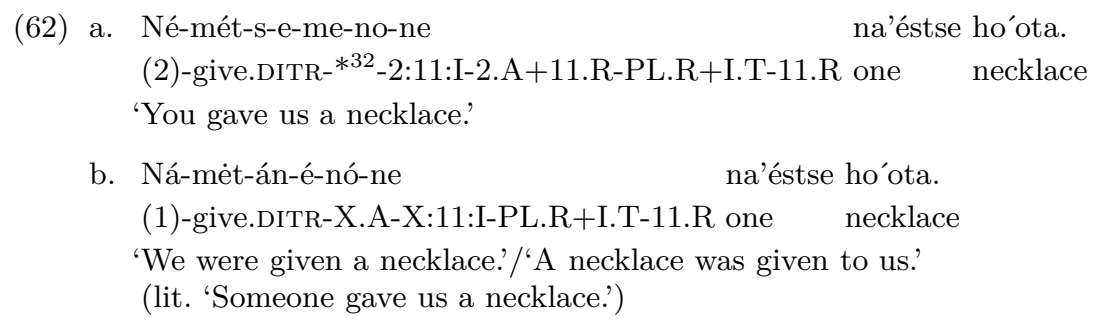

The only possibility of distinguishing between the behaviour of the two objects by means of this construction would be by ascertaining if the prefix refers to the $\mathrm{R}$ or $\mathrm{T}$. Nevertheless, it has not been possible for me to find any examples of a ditransitive construction with either a first or second person $\mathrm{T}^{33}$ or with an inanimate $\mathrm{R}$, which means that, taking into account the Animacy-Topicality hierarchy, the prefix will always refer to: (1) the $\mathrm{R}$, in cases including a first or second person R, or (2) ambiguously either to the $\mathrm{R}$ or $\mathrm{T}$, in cases including a third, fourth or inanimate $\mathrm{R}$.

Relativization does not help us to ascertain which of the objects behaves in the same way as the monotransitive $\mathrm{P}$ since both $\mathrm{T}$ and $\mathrm{R}$ can be relativized and, consequently, no difference with respect to accessibility to this syntactic construction can be observed:

(63) Móxe’èstoo'o tsé-x-hestān-o náhe hetane.

book CLM-PAST-take.TI-3:I DEIC man

'The book that that man took.'

${ }^{32}$ It must be noted that when the final sound of a verb is /t/, it will become /ts/ when pronouncing the suffix (e.g., mét 'give').

33 The same situation occurs in Delaware, another Algonquian language (Goddard 1979, 37; 152). 
(64) Móxe’èstoo'o tsé-h-mét-òtse ${ }^{34}$ néhe book CLM-PAST-give.DITR-3:4:I DEIC

'hetane náhe kảsováaheho.

man DEIC boy (OBV)

'The book that this man gave to that boy.'

(65) Kàsovááhe tsé-h-mét-òtse néhe hetane móxe'èstoóo. boy CLM-PAST-give.DITR-3:4:I DEIC man book 'The boy to whom this man gave the book.'

In Cheyenne all $\mathrm{P}, \mathrm{T}$, and $\mathrm{R}$ are accessible to relativization and the same construction is used for all three, which leads to the claim that, in terms of this criterion, Cheyenne exhibits a neutral alignment pattern.

Another criterion that does not help us distinguish between $\mathrm{R}$ and $\mathrm{T}$ concerns the formation of constituent questions, since both objects can be questioned within a ditransitive construction:

(66) Hénová'e tsé-h-mét-òtse néhe

what CLM-PAST-give.DITR-3:4:I DEIC

'hetane náhe kảsováaheho.

what CLM-PAST-give.DITR-3:4:I DEIC

'What did this man give to that boy?' ${ }^{35}$

(67) Néváasóho tsé-h-mét-òtse néhe hetane móxe'èstoóo.

who (OBV) CLM-PAST-give.DITR-3:4:I DEIC man book

'Who did this man give the book?'

In these examples both objects, namely the T moxe 'éstoo'o 'book' and the $\mathrm{R}$ náhe käsováaheho 'boy', can be questioned and, consequently, no restrictions on questioning certain arguments are found in Cheyenne.

This language expresses reflexivity and reciprocity in the same way, since both constructions use the same verbal affix, namely -ahtse (Leman 1985; Murray 2008). When the subject in a construction containing this suffix -ahtse is singular, the construction is reflexive. Nevertheless, when

34 The simplification of suffixal agreement in the Conjunct Order is here reflected by the fact that the animacy and number of the semantic secondary object is not marked in the ditransitive verb.

35 Wh-questions with interrogative pronouns are clefted in Cheyenne, so the literal translation of this question would be: 'what is it that this man gave to that boy?'. 
the subject of this type of construction is plural, then the verb is potentially ambiguous in terms of a reflexive or reciprocal reading. Regarding the formation of reflexive and reciprocal ditransitive verbs, it is of particular note that, although the verbal stem of these verbs reflects the number of syntactic arguments they require, it takes an TI or TA inflection, ${ }^{36}$ depending on the animacy of the T. Another interesting point lies in the fact that the presence of the -ahtse suffix allows us to differentiate between the two objects, since it only permits the coreference between A and R, but not between $\mathrm{A}$ and $\mathrm{T}$ :

(68) Ná-mét-àhtsé-nó-ne mákaata.

(1)-give.DITR-REFL/REC-11:11:I.PL.A+I.T-11.A money

'We gave themselves/each other the money.'

(69) Ná-mét-ähtsé-no-ne-o'o matanaévéhóe.

(1)-give.DITR-REFL/REC-11:11:33.33.T-11.A-11.A+33.T police

*'We gave themselves/each other to the police.'

!!! We gave the police to themselves/each other.'

As we can see, there is a preference for $\mathrm{R}$ over $\mathrm{T}$ associated with reflexive and reciprocal constructions, which may be due to the concept of animacy, since Rs can only be animate participants and Ts can only be third person, especially nonhuman participants, and both a reflexive and reciprocal relation normally presuppose animacy on the part of the subject and object, so that $\mathrm{R}$ is a better option than $\mathrm{T}$ for these two syntactic criteria. Accordingly, this leads to the claim that in terms of these two criteria, Cheyenne exhibits secundative alignment.

In Cheyenne it is not possible to genitivize $\mathrm{R}$ or $\mathrm{T}$ in a ditransitive construction. Likewise, I have not been able to find any example of noun incorporation in a ditransitive construction. Accordingly, this implies that neither of these two criteria plays a role in differentiating between the two objects.

By contrast, I have discovered that the two objects show different behaviour in terms of the direct-inverse marking exhibited by Cheyenne. Thus, direct-inverse marking shows a clear secundative bias since, owing to the restriction that it is not possible to construct ditransitive sentences with inanimate Rs that are prototypically human, or first or second person $\mathrm{Ts}^{37}$ that are prototypically nonhuman, and also to the ranking of argu-

\footnotetext{
${ }^{36}$ Reflexive and reciprocal monotransitive verbs take an AI inflection.

37 Although it is possible to find examples including an equivalent of the English verb introduce (e.g., Náhe hetane/mónekàsováahe é-hénéenovähéséhónoto he-méoono
} 
ments on a prominence scale (i.e., Animacy-Topicality hierarchy) that always favours animate over inanimate participants, only the person of either the $\mathrm{A}$ or $\mathrm{R}$, but not that of $\mathrm{T}$, can appear as a prefix in a verbal complex.

In sum, given the results obtained above, it seems clear that we can assess the alignment type for each coding and behavioural criterion separately so that it is possible to find mismatches. The following chart shows a summary of the alignment types found for the predicate -mét-in terms of both coding and behavioural coding criteria (table 11).

Table 11: Alignment type for the predicate -mét- 'give'

\begin{tabular}{ll}
\hline Criteria & Alignment type \\
\hline 1. Coding criteria & \\
Flagging & Neutral alignment \\
Indexing & Secundative alignment \\
Word order: & \\
a. NPs & Indirective alignment \\
b. Bound forms & Neutral/Secundative alignment \\
2. Behavioural criteria & \\
Passivization & Neutral alignment \\
Nominalization & - \\
Noun incorporation & - \\
Relativization & Neutral alignment \\
Constituent questions & Neutral alignment \\
Reflexivization & Secundative alignment \\
Reciprocalization & Secundative alignment \\
Direct-inverse marking & Secundative alignment \\
\hline
\end{tabular}

This chart shows that, as expected, there is no correlation between coding and behavioural properties when it comes to predicting the alignment pattern of ditransitive constructions in Cheyenne, since behavioural properties do not follow coding properties. Thus, whereas coding properties appear to

tsé-héstoo 'éšeehaese 'That man/boy introduced his sweetheart to his parents', I have not been able to find any sentence including a first or second person $\mathrm{T}$. Furthermore, it seems that nowadays the use of this verb is considered archaic and other less formal expressions (e.g., Heške naa heho é-vése'hanámoho 'He ate with her parents' or Heške naa heho é-a'xaótóho 'He shook hands with her parents') are preferred. 
show a tendency towards neutral alignment, behavioural properties appear to exhibit a clear secundative bias.

Regarding the existence of mismatches, on the one hand, flagging, passivization, relativization, and the formation of constituent questions show neutral alignment, and, on the other hand, indexing, reflexivization, reciprocalization, and direct-inverse marking favour secundative alignment. ${ }^{38}$ This situation is commonly referred to as mixed alignment. Nevertheless, although there are cases of neutral alignment, there is clear evidence in favour of secundative alignment, which highlights the important role that the concept of animacy plays in the grammar of this language, something that can also be extended to all Native American languages. $\mathrm{R}$ and $\mathrm{B}$ participants tend to be more "human" than T participants and the former are, therefore, given more prominence than the latter.

\section{Conclusion}

In this paper I have presented an analysis of the verbal system in Cheyenne. This study describes the paradigms exhibited by Cheyenne predicates in terms of their valence, which allows us more accurately to classify predicates into one-place predicates, two-place predicates, and three-place predicates, paying special attention to the latter. The data relating to Cheyenne ditransitive constructions show the influence of lexical factors on variation in three-participant constructions. It seems, particularly, that the indexation patterns that are available for a specific verb stem are lexically determined, since some ditransitive verbs can only crossreference two participants and others can crossreference the three participants. Furthermore, this language has a number of predicates so that, depending on the specificity of its non-subject arguments, it may cross-reference no object argument, only the $\mathrm{T}$ or the $\mathrm{R}$, or both of them. With respect to other types of three-place predicates, such as benefactive and causative constructions, it is possible to claim that these predicates behave analogously as ditransitive predicates in marking all their three core arguments, provided they represent specific participants.

While the present study does not manage to provide an account of lexical variation in all ditransitive verbs, it nonetheless makes a contribution to existing accounts of three-participant constructions in Algonquian

38 Although the word order of NPs in ditransitive constructions seems to have a preference for indirective alignment, this situation is really exceptional, as noted above. 
languages. I recognize, however, that this is just a beginning and that the lexicon of Cheyenne and especially its verbal morphology still need to be explored and analysed in more detail in order to understand how argument realization works. More specifically, it would be very interesting to ascertain whether other ditransitive verbs also present lexical splits and whether if it is possible to construct a ditransitive structure in Cheyenne with a first or second person $\mathrm{T}$ and/or with an inanimate $\mathrm{R}$.

\section{References}

Bickel, Balthasar and Johanna Nichols. 2009. Case marking and alignment. In A. Malchukov and A. Spencer (eds.) The Oxford handbook of case. Oxford: Oxford University Press. 304-321.

Blansitt, Edward L. Jr. 1973. Bitransitive clauses. Working Papers on Language Universals 13. $1-26$.

Bliss, Heather and Karen Jesney. 2005. Resolving hierarchy conflict: Local obviation in Blackfoot. Calgary Papers in Linguistics 26. 92-116.

Bloomfield, Leonard. 1946. Algonquian. In C. Osgood and H. Hoijer (eds.) Linguistic structures of Native America (Viking Fund Publications in Anthropology 6). New York: Viking Fund. 85-129.

Dik, Simon. 1997. The theory of Functional Grammar. Complex and derived constructs. Berlin \& New York: Mouton de Gruyter.

Dryer, Matthew S. 1986. Primary object, secondary objects, and antidative. Language 62. 808-845.

É. Kiss, Katalin. 1995. Introduction. In K. É. Kiss (ed.) Discourse configurational languages. Oxford: Oxford University Press. 3-27.

Faltz, Leonard M. 1978. On indirect objects in universal syntax. Chicago Linguistic Society 14. $76-87$.

Fisher, Louise, Wayne Leman, Leroy Pine Sr. and Marie Sanchez. 2006. Cheyenne dictionary. Lame Deer, MT: Chief Dull Knife College.

Gensler, Orin D. 2003. Object ordering in verbs marking two pronominal objects: Nonexplanation and explanation. Linguistic Typology 7. 187-231.

Goddard, Ives. 1979. Delaware verbal morphology. New York: Garland.

Hale, Kenneth L. 1983. Warlpiri and the grammar of non-configurational languages. Natural Language and Linguistic Theory 1. 5-47.

Haspelmath, Martin. 2005. Argument marking in ditransitive alignment types. Linguistic Discovery 3. 1-21.

Hockett, Charles F. 1996. Voice in Algonquian verbs: A suggestion. In J. D. Nichols and A. C. Ogg (eds.) nikotwāsik iskwāhtēm, pāskihtēpayih! Studies in honour of Hans Christoph Wolfart. Winnipeg: Algonquian and Iroquoian Linguistics. 257-261.

Jelinek, Eloise. 1984. Empty categories, case and configurationality. Natural Language and Linguistic Theory 2. 39-76. 
Leman, Elena. 1991. Word order of major constituents in Cheyenne narratives. MA thesis. University of Oregon.

Leman, Wayne. 1980a. Cheyenne texts: An introduction to Cheyenne literature (Occasional Publications in Anthropology, Linguistics Series 6). Greeley: Museum of Anthropology, University of Northern Colorado.

Leman, Wayne. 1980b. A reference grammar of the Cheyenne language, volumes 1 and 2 (Occasional Publications in Anthropology, Linguistics Series 5). Greeley: Museum of Anthropology, University of Northern Colorado.

Leman, Wayne. 1985. Cheyenne pronouns and pronominal functions. Ms. University of Oregon.

Leman, Wayne. 1987. Náévâhóó'ôhtséme. We are going back home: Cheyenne history and stories told by James Shoulderblade and others. Memoir 4. Winnipeg: Algonquian and Iroquoian Linguistics.

Malchukov, Andrej L., Martin Haspelmath and Bernard Comrie (eds.). 2010. Studies in ditransitive constructions: A comparative handbook. Berlin \& New York: Walter de Gruyter.

Meeussen, Achilles E. 1962. The independent order in Cheyenne. Orbis 11. 260-288.

Murray, Sarah E. 2008. Reflexivity and reciprocity with(out) underspecification. In A. Grönn (ed.) Proceedings of Sinn und Bedeutung 12 (2007). Oslo: University of Oslo, ILOS. 455-469.

Petter, Rodolphe. 1952. Cheyenne grammar. Newton, KS: Mennonite Publication Office.

Planck, Frans (ed.). 1979. Ergativity: Towards a theory of grammatical relations. New York: Academic Press.

Primus, Beatrice. 1998. The relative order of recipient and patient in the languages of Europe. In A. Siewierska (ed.) Constituent order in the languages of Europe. Berlin \& New York: Mouton de Gruyter. 421-474.

Primus, Beatrice. 1999. Cases and thematic roles: ergative, accusative and active. Tübingen: Niemeyer.

Rhodes, Richard A. 2010. Ditransitive constructions in Ojibwe. In Malchukov et al. (2010, 626-650).

Russell, Dale W. 1987. Cheyenne verb agreement in GPSG. Doctoral dissertation. University of Illinois at Urbana-Champaign.

Russell, Lena, Inge Genee, Eva Van Lier and Fernando Zuñiga. 2012. Referential hierarchies in three-participant constructions in Blackfoot: The effects of animacy, person, and specificity. Linguistic Discovery 10. 55-79.

Siewierska, Anna. 1996. Word order type and alignment type. Sprachtypologie und Universalienforschung 49. 149-176.

Siewierska, Anna. 2003. Person agreement and the determination of alignment. Transactions of the Philological Society 101. 339-370.

Siewierska, Anna and Dik Bakker. 2007. Bound person forms in ditransitive clauses revisited. Functions of Language 14. 103-125.

Tesnière, Lucien. 1959. Éléments de syntaxe structurale. Paris: Klincksieck.

Wolvengrey, Arok. 2011. Semantic and pragmatic functions in Plains Cree syntax. Doctoral dissertation. University of Amsterdam.

Zwicky, Arnold M. 1977. On clitics. Bloomington, IN: Indian University Linguistics Club. 


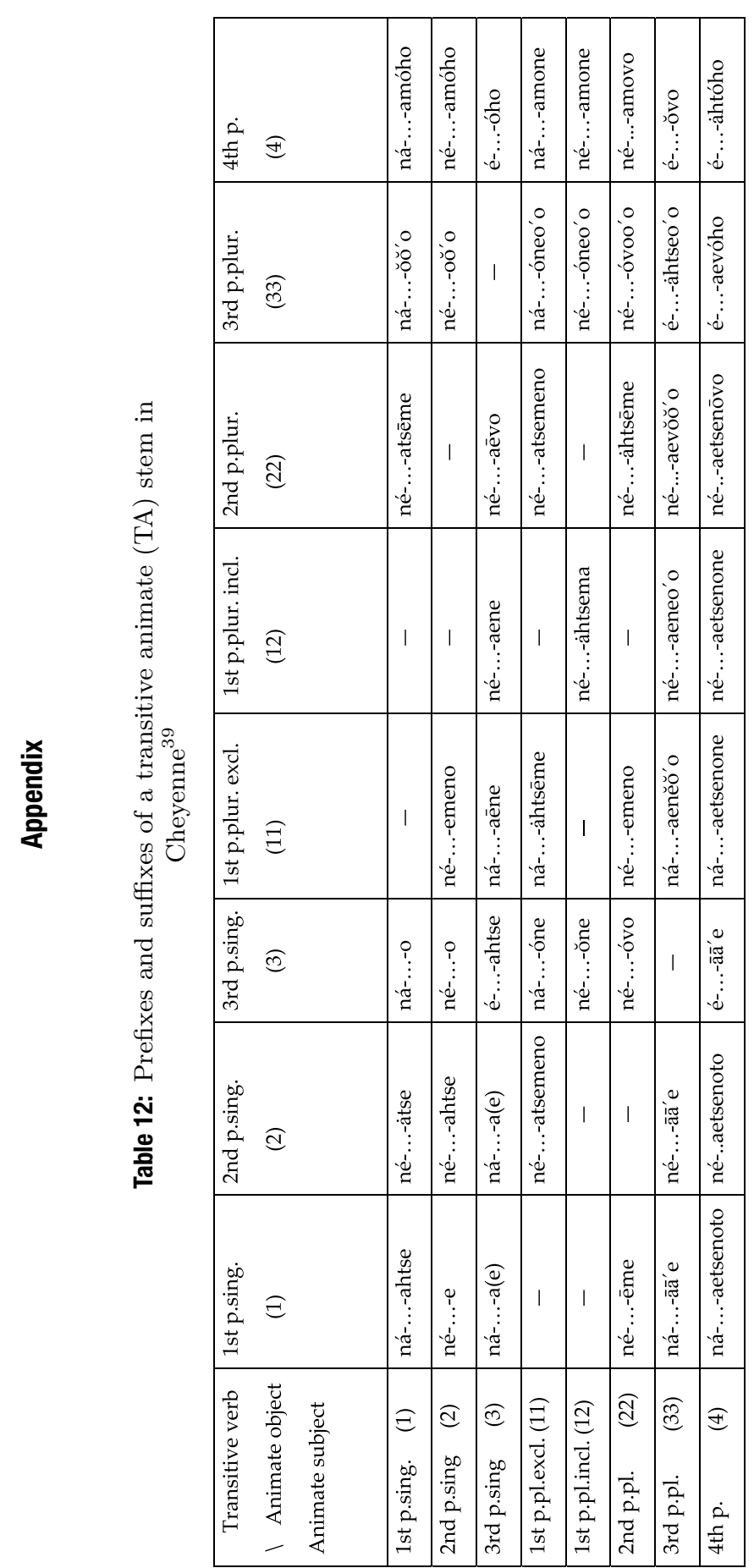

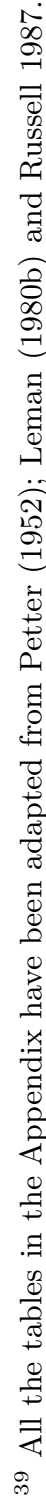




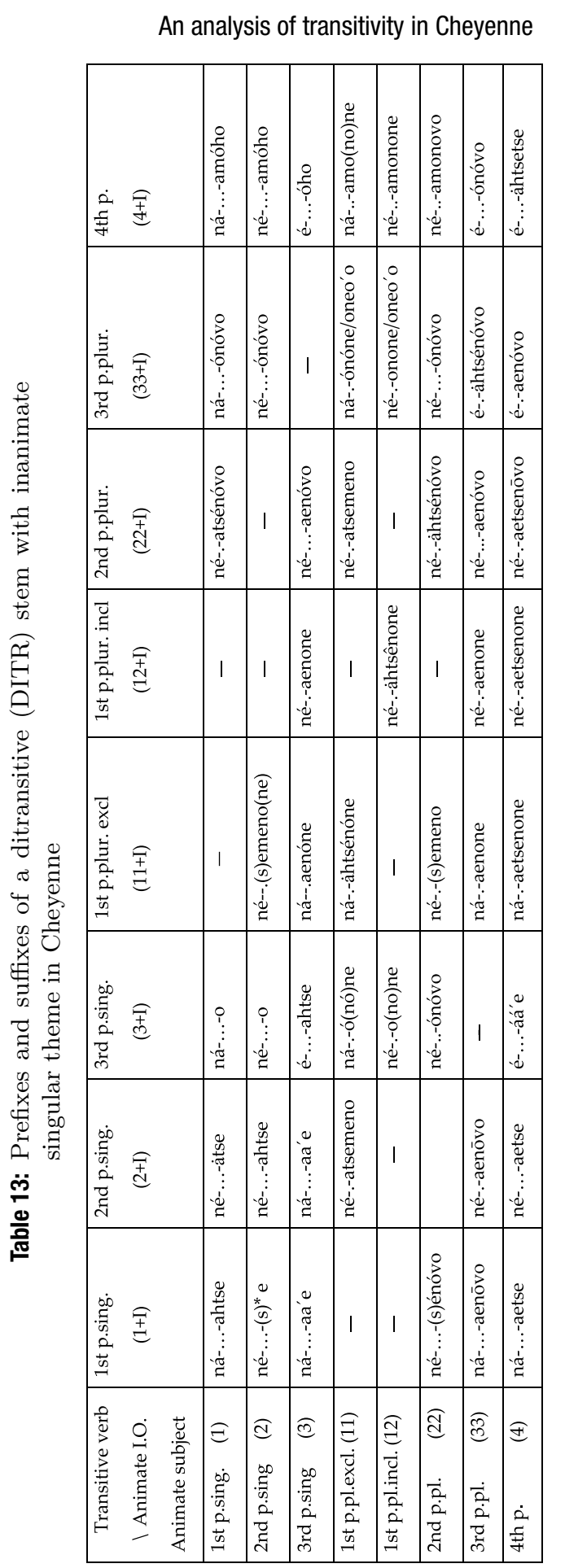

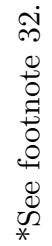




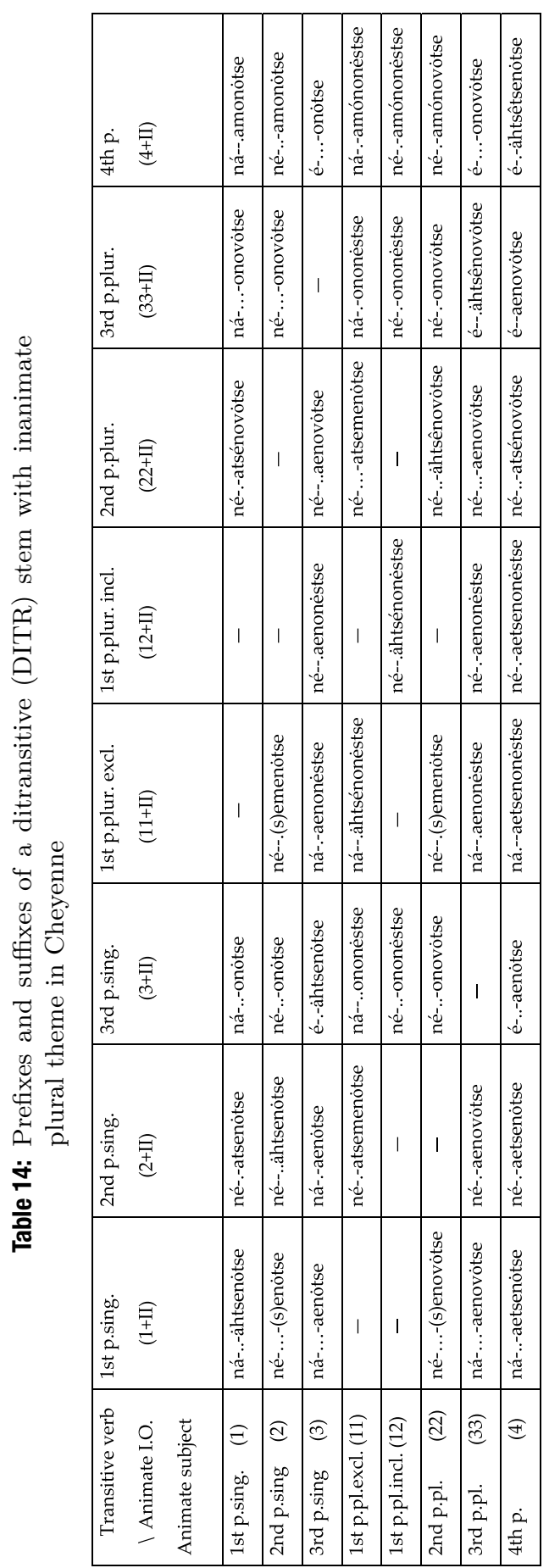

Acta Linguistica Hungarica 61, 2014 


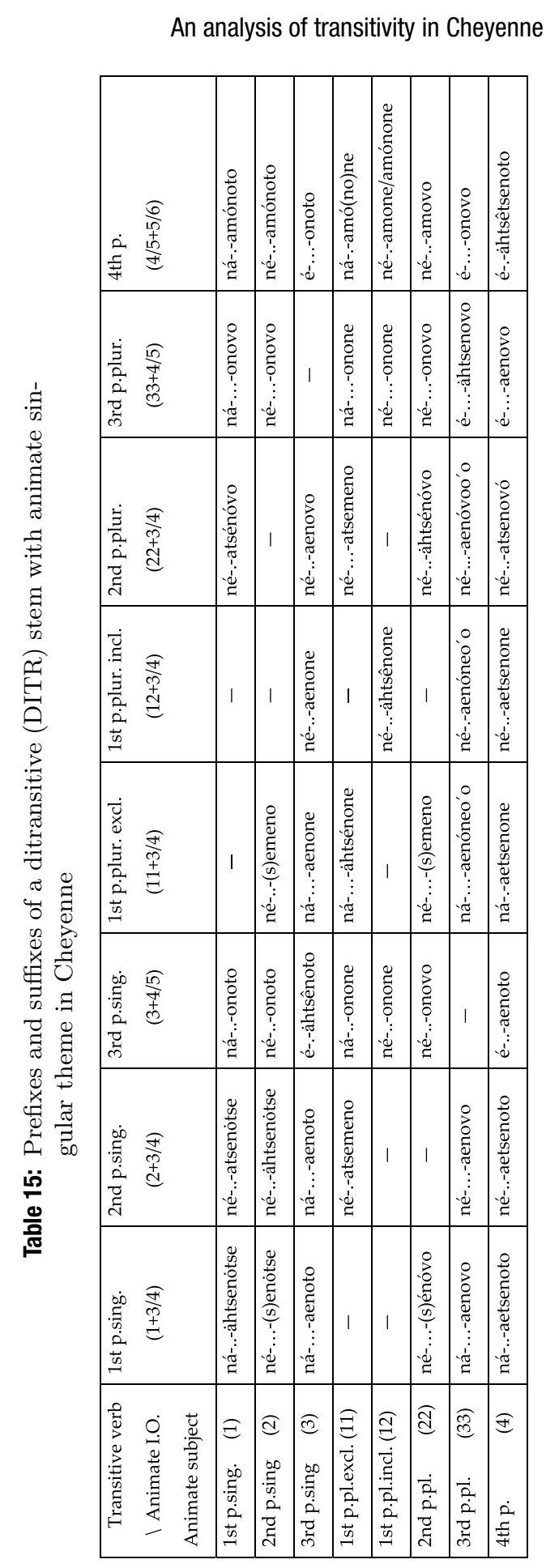

Acta Linguistica Hungarica 61, 2014 


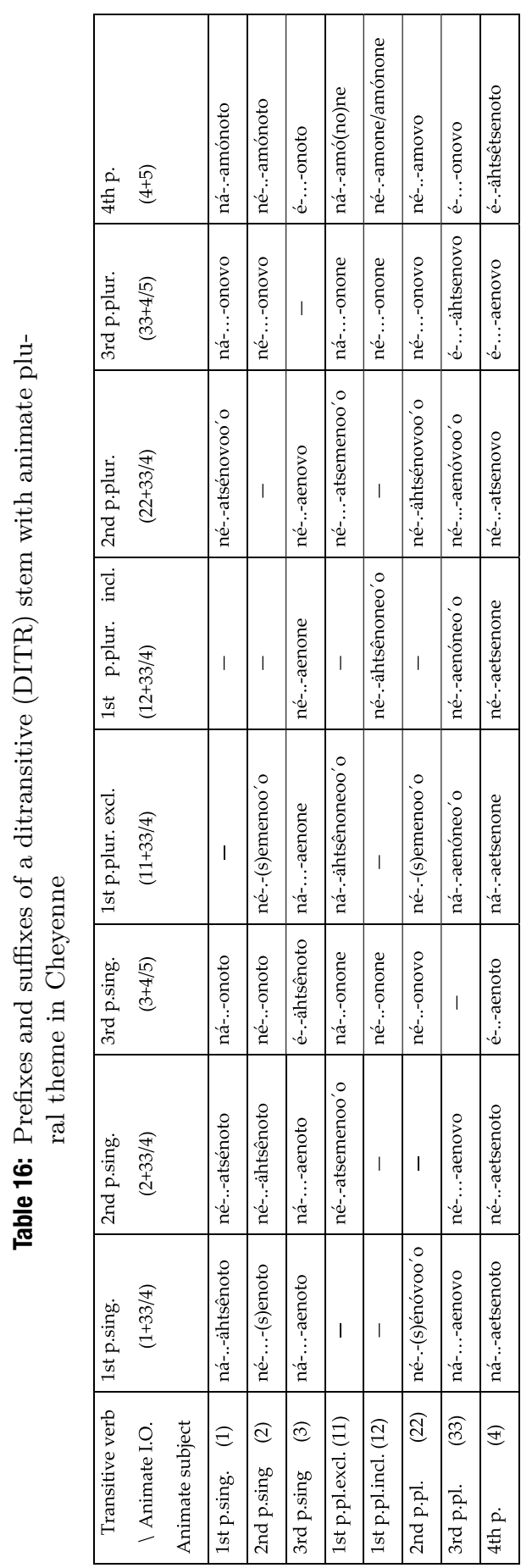

Acta Linguistica Hungarica 61, 2014 